\title{
ODNOS NAVIKA KONZUMACIJE ALKOHOLA I PERCEPCIJE RODITELJSKIH PONAŠANJA KOD ADOLESCENATA SPLITSKO-DALMATINSKE ŽUPANIJE
}

\section{RELATIONSHIP BETWEEN ALCOHOL CONSUMPTION HABITS AND THE PERCEPTION OF PARENTAL BEHAVIORS AMONG ADOLESCENTS IN THE SPLIT-DALMATIA COUNTY}

\begin{abstract}
Roberta Matković
Nastavni zavod za javno zdravstvo Splitsko-dalmatinske županije, Split, Hrvatska Teaching Institute of Public Health, Split-Dalmatia County, Split, Croatia

E-mail: roberta.matkovic@nzjz-split.hr

Ana Petak

Fakultet hrvatskih studija, Zagreb, Hrvatska Faculty of Croatian Studies, Zagreb, Croatia

Željko Ključević

Nastavni zavod za javno zdravstvo Splitsko-dalmatinske županije, Split, Hrvatska Teaching Institute of Public Health, Split-Dalmatia County, Split, Croatia
\end{abstract}

\begin{abstract}
SAŽETAK
Konzumacija alkohola adolescenata rizična je zbog niza kratkoročnih i dugoročnih posljedica. Neprijeporan je utjecaj obitelji na početak konzumacije te na učestalo i prekomjerno pijenje, što je objašnjeno nizom rizičnih i zaštitnih čimbenika obiteljskog okruženja. Njihovo poznavanje i prepoznavanje pomaže u osmišljavanju učinkovitih preventivnih programa radi smanjivanja prevalencije konzumacije alkohola djece i mladih. U školskoj godini 2019./2020. provedeno je istraživanje na stratificiranom uzorku. Sudjelovalo je 1409 učenika (48,3\% mladića i 51,7\% djevojaka) u dobi od 13 do 19 godina ( $M=15,84$; SD = 1,46) iz 16 osnovnih (osmi razred) i 20 srednjih škola (sva četiri razreda) s područja Splitsko-dalmatinske županije. Cilj je rada utvrditi odnos konzumacije alkohola među adolescentima s njihovom percepcijom roditeljskog nadzora, očekivanih roditeljskih reakcija na opijanje te zadovoljstvom odnosa s roditeljima, ali i ponuditi uvid u trenutačne navike konzumacije alkohola među adolescentima Splitsko-dalmatinske županije. Utvrđene su razlike u navikama konzumacije alkohola s obzirom na rod i razred. U usporedbi s učenicima koji manje piju, učenici skloniji konzumaciji alkohola rjeđe smatraju da postoje pravila
\end{abstract}


ponašanja izvan kuće, da njihovi roditelji znaju gdje su i s kim se druže te misle da bi reakcije njihovih roditelja na opijanje bile blaže. Konzumacija alkohola nije se pokazala povezanom sa zadovoljstvom odnosa s roditeljima. Rod, dob, percepcija nadzora i očekivane roditeljske reakcije na opijanje predviđaju 33,7\% varijabiliteta konzumacije alkohola u životu i 22,3\% varijabiliteta konzumacije u posljednjih mjesec dana. Dob, rod, percepcija roditeljskog nadzora, očekivane reakcije roditelja na opijanje i učestalost konzumacije alkohola u posljednjih mjesec dana predviđaju zajedno 40,3\% varijabiliteta učestalosti opijanja u životu i $24,3 \%$ varijabiliteta učestalosti opijanja u posljednjih mjesec dana.

Ključne riječi: navike pijenja, adolescenti, percepcija roditeljskog nadzora, percepcija odnosa s roditeljima, očekivane reakcije roditelja

\begin{abstract}
Alcohol consumption in adolescents is a risk factor for several short- and long-term consequences. The impact of the family on starting with alcohol consumption and on frequent and excessive drinking is indisputable, which is explained through a series of risk and protective factors of the family environment. Awareness of these factors helps in designing effective prevention programs for reducing the prevalence of alcohol consumption among children and young people. During the school year 2019/20, a study was conducted on a stratified sample. The study included 1409 students (48.3\% boys and $51.7 \%$ girls) aged 13 to $19(M=15.84, S D=1.46)$ from 16 primary (eighth grade) and 20 secondary schools (all four grades) from the Split-Dalmatia County. The aim was to determine the relationship between adolescents' alcohol consumption and their perception of parental monitoring, expected parental reactions to intoxication, and satisfaction with relations with parents, but also to provide an insight into current alcohol consumption habits among adolescents in the Split-Dalmatia County. The results show differences in alcohol consumption habits with respect to gender and school grade. Compared to students who drink less, the perception of students who are more prone to alcohol consumption is that their parents are both less likely to have rules of conduct outside home, and are often unaware of where and who their children socialize with. In addition, their expected parental reactions to drinking are milder. A correlation between alcohol consumption and satisfaction with parent-child relations was not established. Gender, age, school, perceived monitoring, and perceived parental reactions predict $33.7 \%$ of variability of alcohol consumption ever in life and $22.3 \%$ variability of alcohol consumption in previous month. Age, gender, perceived monitoring, perceived parental reactions to intoxication and frequency alcohol consumption in previous month together predict $40.3 \%$ of variability of frequency of intoxication ever in life, and $24.3 \%$ variability of frequency of intoxication in previous month.
\end{abstract}

Keywords: drinking habits, adolescents, perceived parental monitoring, perceived relations with parents, perceived parental reactions

\section{UVOD}

Konzumacija alkohola mladih rizična je zbog niza kratkoročnih i dugoročnih posljedica. lako su razni oblici rizičnih ponašanja učestali u adolescenciji kao dio prirodnoga procesa odrastanja, osobito zabrinjava sve niža dob početka konzumacije alkohola. Na globalnoj razini bilježi se dramatičan porast konzumacije alkohola nakon 12. godine te postupno povećanje stopa s godinama (Currie i sur., 2012). U Hrvatskoj je 20,4\% mladih prvo alkoholno piće popilo do 14

\section{INTRODUCTION}

Alcohol consumption is risky for young people due to a number of short- and longterm consequences. Although various forms of risk behaviors are common in adolescence as part of the natural process of growing up, the decreasing age of alcohol consumption is of particular concern. At the global level, there is a dramatic increase in alcohol consumption after the age of 12 , followed by a gradual increase in rates over the years (Currie et al., 2012). In 
godina, a vrlo je mali udio (3,9\%) onih koji su prvo alkoholno piće konzumirali s 22 godine ili kasnije (Glavak Tkalić, Miletić, Maričić i Wertag, 2012). Mladi koji počinju piti s 14 godina ili ranije imaju četiri puta veću vjerojatnost da će u nekom trenutku svojega života ispuniti kriterije za ovisnost o alkoholu nego oni koji su počeli piti nakon 21. godine (National Institute on Alcohol Abuse and Alcoholism [NIAAA], 2004). Rana konzumacija alkohola povezana je $s$ većom vjerojatnošću učestale i prekomjerne konzumacije alkohola u adolescenciji, opijanja i pijanstva (Jackson, Barnett, Colby i Rogers, 2015) te posljedično i razvojem alkoholizma u odrasloj dobi (Livingston, Laslett i Dietze, 2008; Waller, Murray, Shaw, Forbes i Hyde, 2019). Iz svega izloženoga možemo zaključiti da bi prevencija konzumacije alkohola trebala biti društveni i javnozdravstveni prioritet jer ima veliki utjecaj ne samo na zdravlje pojedinca nego i na dobrobit čitave zajednice (Inchley i sur., 2018).

Od 1995. godine provodi se Europsko istraživanje o pušenju, pijenju alkohola i uzimanju droga među učenicima (European School Survey Project on Alcohol and Other Drugs [ESPAD]), međunarodno istraživanje koje prikuplja podatke među mladima u dobi od petnaest-šesnaest godina. Prema spomenutom istraživanju konzumacija alkohola među petnaestogodišnjacima izrazito je visoka, a hrvatski adolescenti piju iznad europskog prosjeka (Pejnović Franelić i sur., 2016). U zadnjem valu istraživanja provedenom 2019. godine $90 \%$ hrvatskih petnaestogodišnjaka bar jednom u životu konzumiralo je alkohol, a 58\% ga je konzumiralo posljednjih mjesec dana. Svaki treći petnaestogodišnjak u europskom uzorku prvo alkoholno piće popio je s 13 godina ili ranije dok je u hrvatskom uzorku ranu konzumaciju prijavilo 42\% sudionika (ESPAD Group, 2020a; 2020b). Europski i hrvatski trendovi konzumacije alkohola među mladima zabrinjavajući su,
Croatia, $20.4 \%$ of young people had their first alcoholic drink before the age of 14 , while only a very small share $(3.9 \%)$ consumed their first alcoholic drink at 22 years or later (Glavak Tkalić, Miletić, Maričić and Wertag, 2012). Young people who start drinking at the age of 14 or earlier are four times more likely to meet the criteria for alcohol addiction at some point in their lives than those who started drinking after the age of 21 (National Institute on Alcohol Abuse and Alcoholism [NIAA], 2004). Early alcohol consumption is associated with a higher probability of frequent and excessive alcohol consumption in adolescence, including binge drinking and intoxication (Jackson, Barnett, Colby and Rogers, 2015) and, consequently, development of adult alcoholism (Livingston, Laslett and Dietze, 2008; Waller, Murray, Shaw, Forbes and Hyde, 2019). All this points to a conclusion that the prevention of alcohol consumption should be a social and public health priority because it has a great impact, not only on individual, but also on the well-being of the entire community (Inchley et al., 2018).

The European School Survey Project on Alcohol and Other Drugs (ESPAD), an international survey collecting data among young people aged 15-16, has been carried out since 1995. According to this research, alcohol consumption in 15-year-olds is exceptionally high, with Croatian adolescents drinking above the European average (Pejnović Franelić et al., 2016). According to the last round of the research, conducted in 2019, $90 \%$ of Croatian 15-yearolds had consumed alcohol at least once in their lives, and $58 \%$ had consumed it in the previous month. One in three 15 -year-olds in the European sample had the first alcoholic drink at the age of 13 or earlier, while $42 \%$ of the respondents reported early consumption in the Croatian sample (ESPAD Group, 2020a; 2020b). European and Croatian trends in alcohol consumption among young people are 
stoga su epidemiološki podatci i detektiranje čimbenika koji doprinose pijenju mladih od prioritetne važnosti za planiranje pravovremenih i učinkovitih preventivnih intervencija.

\section{Neke odrednice utjecaja roditelja i roditeljstva na konzumaciju alkohola kod adolescenata}

Društvene promjene u smjeru sve veće modernizacije, informatizacije i tehnološkog napretka vode do promjena životnog stila pojedinca, obitelji i šireg društva (Merkle i Richardson, 2000). Pri tome se obitelj pokazala kao najotporniji dio društva jer, unatoč mijenjanju i evoluiranju (DeFrain, 2001), obitelj je zadržala svoju temeljnu svrhu, a to je, među ostalim, odgoj i socijalizacija djece te pružanje emocionalne podrške članovima obitelji (Ferić, 2002). Teorija ekološkog sustava (Bronfenbrenner, 1974) naglašava ulogu obitelji u djetetovu psihološkom razvoju te pretpostavlja međusobnu interakciju značajki djeteta i njegove okoline. Okolina djeteta sastoji se od nekoliko razina koje su u međusobnom djelovanju, pri čemu je obitelj, kao razina mikrosustava, najvažniji čimbenik u cjelokupnom djetetovu razvoju. Utjecaji roditelja u interakciji su s naslijeđenim djetetovim obilježjima, mijenjaju ih te uče dijete znanjima, socijalnim vještinama i ključnim elementima kulture, no jednako tako mogu doprinijeti i razvoju emocionalnih poteškoća i problema u ponašanju (Desjardins, Zelenski i Coplan, 2008; Kurdek, 2003; Lengua, Honorado i Bush, 2007; Meunier i sur., 2011; SkreitulePikse, Sebre i Lubenko, 2010).

Prema tome, pozitivan razvoj djece uvelike ovisi o obiteljskom okruženju gdje je obitelj važan čimbenik i zaštite i rizika za razvoj poremećaja u ponašanju djece (Ferić, 2002). Detektiranje i međuodnos rizičnih i zaštitnih čimbenika koji mogu utjecati na razvoj djeteta, bilo na razini pojedinca bilo na razini okoline $\mathrm{u}$ therefore worrying, making epidemiological data and detection of factors contributing to young people's drinking a priority for planning timely and effective preventive interventions.

\section{Selected Determinants of Parental Influence and the Impact of Parenting on Alcohol Consumption in Adolescents}

Social changes towards increasing modernization, IT uptake and technological progress have led to changes in the lifestyle of individuals, families and wider society (Merkle and Richardson, 2000). At the same time, the family proved to be the most vigorous part of society, because, despite changing and evolving (DeFrain, 2001), the family has maintained its basic purpose, including raising and socializing children and providing emotional support to family members (Ferić, 2002). The ecological systems theory (Bronfenbrenner, 1974) emphasizes the role of the family in the child's psychological development, assuming an interaction between the characteristics of the child and its environment. The child's environment consists of several interacting levels, where the family, as a part of the microsystem level, constitutes the most important factor in the overall development of the child. The parents' influences interact with the inherited characteristics of the child, change them, and teach the child knowledge, social skills and key elements of culture, but can also contribute to the development of emotional and behavioral problems (Desjardins, Zelenski and Coplan, 2008; Kurdek, 2003; Lengua, Honorable and Bush, 2007; Meunier et al., 2011; Skreitule-Pikse, Sebre and Lubenko, 2010).

The child's positive development thus largely depends on the family environment where the family is an important factor in both protection and risk for the development of behavioral 
ovom slučaju obitelji) osnova je koncepta rizika

i zaštite. Rizični čimbenici su sva ona obilježja koja mogu utjecati na razvoj poteškoća u ponašanju (Bašić, 2009), dok su zaštitni čimbenici sva ona obilježja koja mogu umanjiti poteškoće u ponašanju (Pollard, Hawkins i Arthur, 1999). Učinkoviti se principi prevencije oslanjaju na promicanje zdravlja jačanjem zaštitnih čimbenika i prevencijom poteškoća ublažavanjem i/ ili uklanjanjem rizičnih čimbenika.

Jedan je od često istraživanih rizičnih/zaštitnih čimbenika za razvoj djeteta odnos $\mathrm{s}$ roditeljima. Odnos roditelja i djeteta, u smislu osjećaja povjerenja između roditelja i djeteta, njegovanja pozitivnih obiteljskih odnosa te roditeljske uključenosti u procese djetetova odrastanja i razvoja, doprinose sprečavanju brojnih neželjenih i problematičnih ishoda u ponašanju (Hawkins, Catalano i Miller, 1992). Brojni nalazi povezuju konflikte u obitelji s delinkventnim ponašanjem djeteta te uporabom svih sredstava ovisnosti (Hemphill, Heerde i Herrenkohl, 2011; Catalano, Hawkins, Berglund, Pollard i Arthur, 2002). Primijećeno je da su pozitivni obiteljski odnosi povezani s većom bliskošću članova obitelji, manjim stresom kod djece te učenjem pozitivnih socijalnih vještina (Brounstein, Zweig i Gardner, 1998; prema Ferić-Šlehan, 2008).

Roditeljski nadzor i kontrola su među najčešće isticanim zaštitnim čimbenicima maloljetničke konzumacije alkohola (European Monitoring Center for Drugs and Drug Addiction [EMCDDA], 2008). Roditeljska kontrola opisuje se kao znanje i informiranost roditelja o djetetovim aktivnostima, prisutnost roditeljskih pravila i djetetovih obveza, nadgledanje djeteta te disciplina uspostavljena postupcima nagrađivanja i kažnjavanja (Shek, 2006). U skladu s tim, izostanak jasnih obiteljskih pravila i neinformiranost roditelja o djetetovim aktivnostima povezuje se s konzumacijom psihoaktivnih tvari disorders in children (Ferić, 2002). Detection and interrelation of risk and protection factors that can influence the child's development, at an individual or environmental level (in this case the family) forms the basis of the concept of risk and protection. Risk factors include all those characteristics that can influence the development of behavioral difficulties (Bašić, 2009), while protection factors include all those that can reduce behavioral difficulties (Pollard, Hawkins and Arthur, 1999). Effective prevention principles are based on promoting health by strengthening protection factors and preventing difficulties through mitigation and/or removal of risk factors.

One of the often examined risk/protection factors for the child's development is the relationship with parents. The relationship between parents and children, in terms of a sense of trust between parents and children, nurturing positive family relationships and parental involvement in the processes of the child's growth and development, contributes to the prevention of numerous undesired and problematic behavioral outcomes (Hawkins, Catalano and Miller, 1992). Numerous findings connect conflicts in the family with the child's delinquent behavior and use of addictive substances (Hemphill, Heerde and Herrenkohl, 2011; Catalano, Hawkins, Berglund, Pollard and Arthur, 2002). It has been noted that positive family relations are associated with greater closeness of family members, lower stress in children, and learning positive social skills (Brounstein, Zweig and Gardner, 1998; according to Ferić-Šlehan, 2008).

Parental monitoring and control are among the most frequently emphasized protective factors of juvenile alcohol consumption (European Monitoring Centre for Drugs and Drug Addiction [EMCDDA], 2008). Parental control is described as the parents' knowledge 
kod djeteta (Kandel i Andrews, 1987). S druge strane, kvalitetna komunikacija, povjerenje između roditelja i djeteta te visoka razina roditeljske informiranosti o djetetovim aktivnostima smanjuju vjerojatnost pojave problematičnih ponašanja kod djece (Mihić, Musić i Bašić, 2013).

Netolerantni stavovi roditelja prema uporabi sredstava ovisnosti uvelike mogu pozitivno utjecati na maloljetničku konzumaciju alkohola. Model socijalnog razvoja (Cleveland, Feinberg, Bontempo i Greenberg, 2008; Catalano i Hawkins, 1996; prema Mihić i sur., 2013) povezuje stavove roditelja prema asocijalnom ponašanju sa stavovima i ponašanjima djeteta na način da izostanak roditeljske negativne percepcije asocijalnih ponašanja može voditi do neprihvatljivih ponašanja adolescenta. Mihić i suradnice (2013) također su potvrdile da će se izostanak negativne roditeljske percepcije neprimjerena ponašanja odraziti na stavove i vrijednosti djece koja mogu postati sklonija neprimjerenim ponašanjima poput krađa, nasilničkih ponašanja ili konzumacije sredstava ovisnosti. Roditelji koji ne toleriraju uporabu sredstava ovisnosti kod djece, trude se oko discipline djeteta te češće razgovaraju o neprimjerenim ponašanjima, to su sve zaštitni čimbenici za uporabu sredstava ovisnosti među mladima (Bašić i sur., 2008; prema Ferić-Šlehan, 2008).

Obrazovanje roditelja samo je jedan od čimbenika socioekonomskog statusa (SES) koji se pokazao povezanim s pijenjem kod mladih, no važno je naglasiti da rezultati studija nisu dosljedni, što se može pripisati različitim mjerama kao pokazateljima SES (Torikka, KaltialaHeino, Luukkaala i Rimpelä, 2017). Studije koje operacionaliziraju SES kao razinu prihoda i obrazovanje roditelja daju nejasne rezultate o odnosu SES-a i konzumacije alkohola mladih (Hanson i Chen, 2007; Wiles i sur., 2007). S druge strane, roditeljsko obrazovanje povezano je $s$ and information about the child's activities, the existence of parental rules and the child's obligations, child monitoring, and discipline established through reward and punishment procedures (Shek, 2006). Accordingly, a lack of clear family rules and parents who are unaware of the child's activities are associated with consumption of psychoactive substances in children (Kandel and Andrews, 1987). On the other hand, quality communication, trust between parents and children, and a high level of parental information about the child's activities reduce the likelihood of problematic behaviors in children (Mihić, Musić and Bašić, 2013).

Parents' intolerant attitudes towards the use of addictive substances can greatly positively influence juvenile alcohol consumption. The social development model (Cleveland, Feinberg, Bontempo and Greenberg, 2008; Catalano and Hawkins, 1996; according to Mihić et al., 2013) connects parents' attitudes towards asocial behavior with the attitudes and behavior of the child, so that the absence of parental negative perception of asocial behavior can lead to unacceptable behavior in adolescents. Mihić et al. (2013) also confirmed that the absence of negative parental perception of inappropriate behavior affects the attitudes and values of children, who can become more prone to unacceptable behavior such as theft, violent conduct or consumption of addictive substances. Parents who do not tolerate the use of addictive substances in children tend to work on children's discipline and talk more often about inappropriate behaviors, which are all protective factors against the use of addictive substances in young people (Bašić et al., 2008; according to Ferić-Šlehan, 2008).

Parents' education is just one of the factors of socioeconomic status (SES) proven to be related to drinking in young people. However, it is important to emphasize that the results of 
Roberta Matković, Ana Petak, Željko Ključević: Odnos navika konzumacije alkohola i percepcije roditeljskih...

konzumacijom sredstava ovisnosti kod djece (Bjarnason, 2000; Tuinstra, Groothoff, Van Den Heuvel i Post, 1998). Niže obrazovanje roditelja povezano je s češćom konzumacijom alkohola i učestalijim opijanjem među adolescentima (Melotti i sur., 2013; Torikka i sur., 2017). Smatra se da obrazovaniji roditelji potiču zdravija ponašanja kod djece što podrazumijeva i manju učestalost konzumacije alkohola, a više obrazovanje i stabilnost zaposlenja omogućuju i više resursa za superviziju djece u odnosu na resurse koji su dostupni roditeljima manje privilegirane djece (Melotti i sur., 2013). S druge strane, Vrselja i Glavak-Tkalić (2011) nailaze na suprotan smjer te veze pri čemu su djeca obrazovanijih roditelja sklonija delinkventnu i rizičnu ponašanju. Neka od potencijalnih objašnjenja takvih nalaza su manje konvencionalne vrijednosti osoba višeg SES-a te odnosi socijalne moći, pri čemu osobe višeg SES-a imaju i veću socijalnu moć, manji strah od kažnjavanja i stavove koji mogu dovesti do rizičnih ponašanja (Vrselja i Glavak-Tkalić, 2011).

Neprijeporno je da su uz ranije opisane čimbenike i druga obilježja obitelji povezana s konzumacijom alkohola, poput kriminaliteta i učestalosti pijenja među roditeljima, odgojnim metodama, strukturom obitelji i sl. (više u Vrselja i Glavak-Tkalić, 2011). Međutim, možemo primijetiti da se ranije opisane dimenzije nadzora, odnosa roditelja i adolescenata te roditeljskih stavova međusobno isprepleću. $U$ disfunkcionalnim obiteljima, u kojima je roditeljska konzumacija prisutna kao model ponašanja, često su prisutni i neadekvatni stavovi roditelja prema konzumaciji (Bahr, Hoffmann i Yang, 2005). Adolescenti koji učestalo konzumiraju alkohol i druga sredstva ovisnosti značajno učestalije percipiraju navedeni čimbenik u svojoj obitelji od nekonzumenata (Mihić i sur., 2013). Roditeljska konzumacija alkohola može djelovati na djetetovu konzumaciju alkohola disfunkcionalnim obiteljskim odnosima ili manjkom roditeljske studies are not consistent, which can be attributed to various measures used as SES indicators (Torikka, Kaltiala-Heino, Luukkaala and Rimpelä, 2017). Studies that operationalize SES as the level of income and parental education provide inconclusive results on the relation between SES and alcohol consumption in young people (Hanson and Chen, 2007; Wiles et al., 2007). On the other hand, parental education is related to the consumption of addictive substances in children (Bjarnason, 2000; Tuinstra, Groothoff, Van den Heuvel and Post, 1998). Lower levels of parental education are associated with more frequent alcohol consumption and more frequent intoxication among adolescents (Melotti et al., 2013; Torikka et al., 2017). More educated parents are considered to encourage healthier behavior in children, including a lower frequency of alcohol consumption, while higher education levels and stability of employment allow more resources for monitoring children than the resources available to parents of less privileged children (Melotti et al., 2013). Conversely, Vrselja and Glavak-Tkalić (2011) suggest the opposite direction of this relationship, with children of more educated parents prone to delinquent and risky behaviors. Some of the possible explanations for such findings include less conventional values in persons with a higher SES, as well as social power relations, with persons with higher SES also having greater social power, lower fear of punishment, and attitudes that can lead to risky behaviors (Vrselja and Glavak-Tkalić, 2011).

Along with the above described factors, indisputably, there are also other family characteristics that are related to alcohol consumption, such as criminality and frequency of drinking among parents, educational methods, family structure, etc. (more in Vrselja and GlavakTkalić, 2011). It can be noted, however, that the previously described dimensions of monitoring, relations between adolescents and 
podrške (Hung, Yen i Wu, 2009). Ipak, nadzor i disciplina medijatori su veze roditeljske i adolescentove konzumacije alkohola (Latendresse i sur., 2008). Zbog svega navedenog ovaj se rad fokusira na čimbenike rizika za konzumaciju alkohola povezane s dimenzijama roditeljskog nadzora, odnosa roditelja i adolescenata te adolescentske percepcije roditeljskih stavova prema uporabi sredstava ovisnosti.

\section{CILJ I SVRHA ISTRAŽIVANJA}

Cilj je rada utvrditi odnos učestalosti konzumacije alkohola među adolescentima te percepcije roditeljskog nadzora, očekivanih reakcija roditelja na konzumaciju alkohola te zadovoljstva odnosom s roditeljima. Dodatno, cilj je ispitati zajednički doprinos navedenih čimbenika za učestalost konzumacije alkohola među adolescentima, ali i ponuditi uvid u trenutačne navike konzumacije alkohola među adolescentima Splitsko-dalmatinske županije. Navedene spoznaje imaju svrhu opisivanja rizičnih čimbenika za konzumaciju alkohola među mladima, a rezultati se mogu koristiti u pripremi i planiranju preventivnih intervencija. Istraživački problemi su:

1. Opisati navike pijenja (učestalosti konzumacije i učestalost opijanja u životu, u posljednjih 12 mjeseci i u posljednjih mjesec dana) adolescenata Splitsko-dalmatinske županije. Utvrditi razlike u navikama pijenja adolescenata Splitsko-dalmatinske županije s obzirom na sociodemografske varijable (rod, razred, obrazovanje roditelja).

2. Ispitati povezanost adolescentskih navika konzumiranja alkohola s percepcijom roditeljskog nadzora, očekivanim reakcijama roditelja te zadovoljstvom odnosa s roditeljima. their parents, and parental attitudes intertwine. Dysfunctional families where parental drinking is present as a model of behavior often involve parents' inadequate attitudes towards alcohol consumption (Bahr, Hoffmann and Yang, 2005). Adolescents who often consume alcohol and other addictive substances perceive this factor significantly more often in their families than non-drinkers (Mihić et al., 2013). Parental alcohol consumption can affect the child's alcohol consumption through dysfunctional family relations or through a lack of parental support (Hung, Yen and Wu, 2009). However, monitoring and discipline are mediators of the connection between parental and adolescent alcohol consumption (Latendresse et al., 2008). Due to all this, this paper focuses on the risk factors for alcohol consumption related to the dimensions of parental monitoring, parental-adolescent relations, and adolescent perception of parental attitudes towards the use of addictive substances.

\section{AIM AND PURPOSE OF THE RESEARCH}

The aim of this paper is to determine the relationship between the frequency of alcohol consumption among adolescents and the perception of parental monitoring, parents' expected reactions to alcohol consumption, and satisfaction with relations with parents. Additionally, the aim is to examine the joint contribution of these factors to the frequency of alcohol consumption among adolescents, but also to provide insight into current alcohol consumption habits among adolescents in the Split-Dalmatia County. The purpose of the findings is to describe risk factors for drinking alcohol in young people, and the results can be used in preparing and planning preventive interventions. The research problems are as follows: 
3. Ispitati razlike u percepciji roditeljskog nadzora, percepciji očekivanih roditeljskih reakcija na konzumaciju alkohola te zadovoljstvu odnosa s roditeljima među povremenim konzumentima alkoholnih pića i učestalih konzumenata alkoholnih pića.

4. Ispitati zajednički doprinos sociodemografskih varijabli, percepcije roditeljskog nadzora i percepcije očekivanih roditeljskih reakcija na konzumaciju alkohola u predviđanju konzumacije alkohola u životu i u posljednjih mjesec dana.

5. Ispitati zajednički doprinos sociodemografskih varijabli te percepcije roditeljskog nadzora i percepcije očekivanih reakcija roditelja u predviđanju broja opijanja u životu i u posljednjih mjesec dana.

\section{METODOLOGIJA ISTRAŽIVANJA}

\section{Uzorak}

Istraživanje je provedeno u školskoj godini 2019./2020., tijekom redovne nastave u školama. Uzorak je stratificiran (više detalja vidjeti u opisu postupka), a uključene škole odabrane su slučajnim odabirom škola s područja Splitsko-dalmatinske županije radi obuhvata $8 \%$ populacije učenika s područja županije. Škole i razredi odabrani su pomoću generatora slučajnih brojeva. Uzorak je stratificiran prema dobi, vrsti školskog usmjerenja (osnovnoškolski, gimnazijski, četverogodišnji strukovni i trogodišnji strukovni smjer) te prema mjestu školovanja (Split, ostali gradovi i mjesta Splitsko-dalmatinske županije te otoci). Na taj način osigurana je reprezentativnost uzorka prema vrsti škole te prema mjestu pohađanja škole. U istraživanju je sudjelovalo 1409 učenika iz ukupno 16 osnovnih i 20 srednjih škola.
1. Describe the drinking habits (frequency of alcohol consumption and intoxication in life, in the last 12 months and in the last month) of adolescents in the Split-Dalmatia County. Identify differences in the drinking habits of adolescents in the Split-Dalmatia County with regard to socio-demographic variables (gender, school grade, parental education level).

2. Examine the relationship between adolescents' drinking habits with the perception of parental monitoring, parents' expected reactions, and satisfaction with relations with parents.

3. Examine differences in the perception of parental monitoring, parents' expected reactions to alcohol consumption, and satisfaction with relations with parents between occasional and frequent consumers of alcoholic drinks.

4. Examine the joint contribution of socio-demographic variables, the perception of parental monitoring, and parents' expected reactions to alcohol consumption in predicting alcohol consumption in life, and in the last month.

5. Examine the joint contribution of socio-demographic variables, the perception of parental monitoring and parents' expected reactions to alcohol consumption in predicting the number of intoxications in life, and in the last month.

\section{RESEARCH METHODOLOGY}

\section{Sample}

The survey was carried out in the school year 2019/2020, during regular school classes. The sample was stratified (see more details 
Sudjelovaloje 48,3\% mladića i 51,7\% djevojaka u dobi od 13 do 19 godina $(M=15,84 ; S D=1,46)$. Od ukupnog broja 17,1\% učenika pohađalo je osmi razred osnovne škole, 23,2\% prvi razred srednje škole, 19,5\% drugi razred srednje škole, $21,1 \%$ treći razred srednje škole i 19,1\% četvrti razred srednje škole. Četverogodišnje strukovne škole pohađalo je ukupno $45,6 \%$ učenika, gimnazijskog usmjerenja 23,8\% i trogodišnje srednje škole 13,4\% učenika (Tablica 1).

\section{Instrumenti}

Za potrebe istraživanja, koje je proveo Nastavni zavod za javno zdravstvo Splitskodalmatinske županije, primijenjen je modificirani anketni upitnik s nekim područjima procjene prema uzoru na ESPAD metodologiju. Upitnik je sadržavao pitanja za prikupljanje sociodemografskih podataka te pitanja o navikama konzumacije alkohola i ostalih opojnih sredstava na ordinalnim skalama samoprocjene. $\mathrm{Na}$ taj način prikupljeni su podatci o učestalosti konzumacije alkohola u životu, u posljednjih 12 mjeseci i u posljednjih mjesec dana („U koliko si prilika (ako jesi) pio/la alkoholna pića?" - u životu, zadnjih 12 mjeseci i zadnjih 30 dana; od (1) - Nikada, do (7) - 40 ili više puta). Na jednak način procijenjen je broj opijanja učenika u trima različitim periodima: „Koliko si se puta (ako si uopće) opio/la ili bio/la pod jakim utjecajem alkoholnog pića tako da si nesigurno hodao/la, nisi bio/la u stanju pravilno govoriti, povraćao/ la ili se ne sjećaš što se događalo?" - U životu, u posljednjih 12 mjeseci, u posljednjih 30 dana (od (1) - Nikada do (6) - 20 ili više puta). Učenici su procjenjivali zadovoljstvo odnosom s roditeljima („Koliko si općenito zadovoljan/na svojim odnosom s ocem?", "Koliko si općenito zadovoljan/na svojim odnosom s majkom?") na skali procjene od 1 do 5 (1 - Jako nezadovoljan, 5 -Vrlo zadovoljan). Očekivane reakcije roditelja na konzumaciju alkohola učenici su procjenjivali na jednoj čestici, odvojeno za majku i oca („Što in the description of the procedure) and the participating schools were selected at random in the Split-Dalmatia County, with a goal of reaching eight percent of the population of the county's students. The schools and classes were selected using a random number generator. The sample was stratified according to age, type of school (primary school, grammar school, four-year vocational and three-year vocational secondary school) and location (Split, other cities and towns of the Split-Dalmatia County and the islands). This ensured that the sample was representative by the type and location of school. 1409 students from a total of 16 primary and 20 secondary schools participated in the survey. The sample included $48.3 \%$ male and $51,7 \%$ female students aged $13-19(M=15.84$; $S D=1.46)$. Of the total number, $17.1 \%$ of the students attended eighth grade primary school, $23.2 \%$ first grade secondary school, $19.5 \%$ second grade secondary school, $21.1 \%$ third grade secondary school, and $19.1 \%$ fourth grade secondary school. A total of $45.6 \%$ of the students attended four-year vocational schools, 23.8\% attended grammar schools, and $13.4 \%$ attended three-year secondary schools (Table 1).

\section{Instruments}

For purposes of the survey carried out by the Teaching Institute of Public Health of the SplitDalmatia County, a modified questionnaire with some assessment areas similar to the ESPAD methodology was applied. The questionnaire contained questions for the collection of socio-demographic data as well as questions on the habits of consuming alcohol and other addictive substances on ordinal self-assessment scales. This way, data were collected on the frequency of alcohol consumption in life, in the last 12 months, and in the last month ('On how many occasions did you drink alcohol (if at all)?' - ever in life, in the last 12 months, and in the 
misliš kako bi tvoja majka reagirala da učiniš sljedeće? - Opiješ se“, i „Što misliš kako bi tvoj otac reagirao da učiniš sljedeće? - Opiješ se") na skali do 1 do 4 (1 - Ne bi mi dopustio/la do 4-Odobrio/la bi). Znanje roditelja o tome gdje („Moji roditelji znaju gdje provodim večeri.") $\mathrm{i}$ s kim ("Moji roditelji znaju s kim provodim večeri.") adolescent provodi slobodno vrijeme te postojanje pravila ponašanja izvan kuće („Moji roditelji određuju konačna pravila o onome što mogu raditi izvan kuće.") procjenjivane su odgovorima na pojedinačnim česticama, na skali samoprocjene sa stupnjevima od (1) - Gotovo nikad, do (5) - Gotovo uvijek. Isključivo u svrhu sažeta opisivanja varijabli korištenih u analizama te formiranja naziva tablica, u nekim je dijelovima rada percepcija adolescenata o roditeljskom znanju o tome gdje is kime provode večer te o postojanju pravila ponašanja izvan kuće samo konceptualno (ali ne i statistički) objedinjena pod nazivom roditeljski nadzor. $U$ ovom radu bit će prikazan dio rezultata prikupljenih tijekom projekta "Rizična ponašanja djece i mladih Splitsko-dalmatinske županije".

\section{Postupak}

Epidemiološko prikupljanje podataka „Rizična ponašanja djece i mladih Splitskodalmatinske županije" provodio je Nastavni zavod za javno zdravstvo Splitsko-dalmatinske županije uz suglasnost Ministarstva obrazovanja i Agencije za odgoj i obrazovanje, Upravnog odjela za prosvjetu, kulturu i tehničku kulturu Splitsko-dalmatinske županije te uz suglasnost ravnatelja odabrane škole. U pripremi i provedbi istraživanja primijenjena su Etička načela u istraživanju s djecom (2003). Roditelji su bili obaviješteni o provedbi istraživanja, a roditelji djece mlađe od 14 godina svoju su suglasnost potvrdili potpisom. Učenici su popunjavali online upitnik u okviru školskog sata te je obavljena dodatna provjera popunjenih last 30 days; on a scale from (1)- Never to (7)- 40 times or more). The number of intoxications in the three different periods was assessed in the same way: 'How many times (if at all) did you get drunk or were heavily under the influence of alcohol, so much that you walked unsteadily, were unable to speak properly, vomited, or did not remember what happened?' - ever in life, in the last 12 months, and in the last 30 days; on a scale from (1)-Never to (6)- 20 or more times). The students also assessed satisfaction with relations with their parents ('How satisfied are you generally with the relationship with your father?', 'How satisfied are you generally with the relationship with your mother?') on a scale from 1 to 5 (1- Very dissatisfied, 5- Very satisfied). Parents' expected reactions to alcohol consumption were assessed by students on one unit, separately for mother and father ('How do you think your mother would react if you did the following? - Got drunk' and" How do you think your father would react if you did the following? - Got drunk?) on a scale from 1 to 4 (1-They wouldn't allow me to; 4- They would approve of it). The parents' knowledge about where ('My parents know where I spend the evening') and who with ('My parents know who I spend the evening with') the adolescent spends their free time, and the existence of rules of conduct outside home ('My parents set the final rules about what I can do outside home') were assessed through answers on individual units, on a self-assessments scale ranging from (1)- Hardly ever, to (5)- Nearly always. For the sole purpose of summarizing the variables used in the analyses and naming the tables, in some places in the paper the adolescents' perception of parental knowledge of where and who they spend the evening with, and on the existence of rules of conduct outside home is only conceptually (but not statistically) combined under the title 'parental monitoring.' This paper will present some of the findings collected during 
Criminology \& Social Integration Vol 29 (2021) 1, 105 - 144.

Tablica 1. Prikaz karakteristika uzorka prema rodu, razredu, školskom usmjerenju i obrazovanju roditelja

Table 1. Sample characteristics according to gender, school grade, school type and parental education

\begin{tabular}{|c|c|c|c|c|c|}
\hline & & \multicolumn{4}{|c|}{ ROD / GENDER } \\
\hline & & \multicolumn{2}{|c|}{ Muško / Male } & \multicolumn{2}{|c|}{$\begin{array}{l}\text { Žensko / } \\
\text { Female }\end{array}$} \\
\hline & & $\mathbf{N}$ & $\%$ & $\mathbf{N}$ & $\%$ \\
\hline \multirow{4}{*}{$\begin{array}{l}\text { ŠKOLA } \\
\text { SCHOOL }\end{array}$} & $\begin{array}{l}\text { Osnovna škola } \\
\text { Primary school }\end{array}$ & 105 & 15,44 & 136 & 18,66 \\
\hline & $\begin{array}{l}\text { SŠ - trogodišnji strukovni smjer } \\
\text { Secondary school - 3-year vocational }\end{array}$ & 167 & 24,56 & 22 & 3,02 \\
\hline & $\begin{array}{l}\text { SŠ - četverogodišnji strukovni smjer } \\
\text { Secondary school - 4-year vocational }\end{array}$ & 312 & 45,88 & 331 & 45,40 \\
\hline & $\begin{array}{l}\text { SŠ - gimnazijski smjer } \\
\text { Secondary school - grammar school }\end{array}$ & 96 & 14,12 & 240 & 32,92 \\
\hline \multirow{5}{*}{$\begin{array}{l}\text { RAZRED } \\
\text { GRADE }\end{array}$} & $\begin{array}{l}\text { 8. razred OŠ } \\
\text { 8th grade primary school }\end{array}$ & 105 & 15,44 & 136 & 18,66 \\
\hline & $\begin{array}{l}\text { 1. razred SŠ } \\
\text { 1st grade secondary school }\end{array}$ & 167 & 24,56 & 160 & 21,95 \\
\hline & $\begin{array}{l}\text { 2. razred SŠ } \\
\text { 2nd grade secondary school }\end{array}$ & 140 & 20,59 & 135 & 18,52 \\
\hline & $\begin{array}{l}\text { 3. razred SŠ } \\
\text { 3rd grade secondary school }\end{array}$ & 156 & 22,94 & 141 & 19,34 \\
\hline & $\begin{array}{l}\text { 4. razred SŠ } \\
\text { 4th grade secondary school }\end{array}$ & 112 & 16,47 & 157 & 21,54 \\
\hline & & \multicolumn{2}{|c|}{$\mathbf{N}$} & \multicolumn{2}{|c|}{$\%$} \\
\hline \multirow{6}{*}{$\begin{array}{l}\text { OBRAZOVANJE OCA } \\
\text { FATHER'S EDUCATION LEVEL }\end{array}$} & $\begin{array}{l}\text { OŠ ili manje } \\
\text { Primary school or less }\end{array}$ & \multicolumn{2}{|c|}{38} & \multicolumn{2}{|c|}{2,71} \\
\hline & $\begin{array}{l}\text { Stručna škola ( } 2 \text { god SŠ) } \\
\text { Vocational school ( } 2 \text { years secondary school) }\end{array}$ & \multicolumn{2}{|c|}{73} & \multicolumn{2}{|c|}{5,20} \\
\hline & $\begin{array}{l}\text { Srednja škola ( } 3 \text { ili } 4 \text { god) } \\
\text { Secondary school ( } 3 \text { or } 4 \text { years) }\end{array}$ & \multicolumn{2}{|c|}{594} & \multicolumn{2}{|c|}{42,31} \\
\hline & $\begin{array}{l}\text { Viša škola } \\
\text { College }\end{array}$ & \multicolumn{2}{|c|}{172} & \multicolumn{2}{|c|}{12,25} \\
\hline & \begin{tabular}{|l} 
Fakultet \\
University
\end{tabular} & \multicolumn{2}{|c|}{307} & \multicolumn{2}{|c|}{21,87} \\
\hline & $\begin{array}{l}\text { Nepoznato } \\
\text { Unknown }\end{array}$ & \multicolumn{2}{|c|}{225} & \multicolumn{2}{|c|}{16,03} \\
\hline \multirow{6}{*}{$\begin{array}{l}\text { OBRAZOVANJE MAJKE } \\
\text { MOTHER'S EDUCATION LEVEL }\end{array}$} & $\begin{array}{l}\text { OŠ ili manje } \\
\text { Primary school or less }\end{array}$ & \multicolumn{2}{|c|}{25} & \multicolumn{2}{|c|}{1,78} \\
\hline & $\begin{array}{l}\text { Stručna škola ( } 2 \text { god SŠ) } \\
\text { Vocational school ( } 2 \text { years secondary school) }\end{array}$ & \multicolumn{2}{|c|}{42} & \multicolumn{2}{|c|}{2,99} \\
\hline & $\begin{array}{l}\text { Srednja škola ( } 3 \text { ili } 4 \text { god) } \\
\text { Secondary school ( } 3 \text { or } 4 \text { years) }\end{array}$ & \multicolumn{2}{|c|}{566} & \multicolumn{2}{|c|}{40,31} \\
\hline & $\begin{array}{l}\text { Viša škola } \\
\text { College }\end{array}$ & \multicolumn{2}{|c|}{178} & \multicolumn{2}{|c|}{12,68} \\
\hline & \begin{tabular}{|l} 
Fakultet \\
University
\end{tabular} & \multicolumn{2}{|c|}{406} & \multicolumn{2}{|c|}{28,92} \\
\hline & $\begin{array}{l}\text { Nepoznato } \\
\text { Unknown }\end{array}$ & \multicolumn{2}{|c|}{192} & \multicolumn{2}{|c|}{13,68} \\
\hline
\end{tabular}


Roberta Matković, Ana Petak, Željko Ključević: Relationship Between Alcohol Consumption Habits and the...

upitnika pomoću dnevnika anketiranja koji su popunjavali razrednici.

\section{REZULTATI}

Raspodjele učestalosti konzumacije alkohola i učestalosti opijanja odstupaju od normalne raspodjele što je očekivano za raspodjelu konzumacije sredstava ovisnosti kod mladih. Dok indeks asimetrije raspodjele konzumacije alkohola u životu ne prelazi vrijednost 1,96, indeksi asimetrije opijanja te raspodjela konzumacije alkohola u posljednjih mjesec i godinu dana prelaze vrijednost 1,96 što je granično za tretiranje distribucije kao normalne (Pett, 2016), stoga su rezultati obrađeni neparametrijskim postupcima analiza.

\section{Opis navika pijenja te razlike u navikama pijenja adolescenata Splitsko-dalmatinske županije s obzirom na sociodemografske varijable}

Rezultati prikazani u Tablici 2 pokazuju da je 83,7\% učenika barem jednom u životu konzumiralo alkoholna pića, 73,9\% učenika konzumiralo je alkohol u posljednjih godinu dana, a 53,9\% učenika u posljednjih mjesec dana. Barem jednom u životu bilo je u stanju opijenosti $44,6 \%$ učenika, pri čemu je $34,6 \%$ učenika iskusilo pijanstvo barem jednom u posljednjih godinu dana, a $16 \%$ u posljednjih mjesec dana.

Rezultati iz Tablice 3 pokazuju da su mladići u odnosu na djevojke općenito skloniji konzumaciji alkohola.

Učenici viših razreda značajno više konzumiraju alkohol od učenika nižih razreda u svim trima mjerenim varijablama (u životu, u godini dana, u mjesec dana), pri čemu su razlike između gotovo svakog uspoređenog the project 'Risk behaviors of children and young people in the Split-Dalmatia County'.

\section{Procedure}

Epidemiological data collection under the project 'Risk Behaviors of Children and Young People in the Split-Dalmatia County' was carried out by the Teaching Institute of Public Health of the Split-Dalmatia County, with an approval of the Ministry of Education and the Education and Teacher Training Agency (ETTA), Administrative Department for Education, Culture and Technical Culture of the Split-Dalmatia County, and a consent of the headmaster of each selected school. The Ethical Principles in Research with Children (2003) were applied in preparing and conducting the research. Parents were informed about the research, and parents of the children under the age of 14 confirmed their consent with their signatures. Students completed the online questionnaire during school classes, and completed questionnaires were additionally checked using the survey logs filled in by the class teachers.

\section{FINDINGS}

Distributions of the frequency of alcohol consumption and frequency of intoxication deviate from normal, as expected for the distribution of addictive substances in young people. While the alcohol consumption distribution asymmetry index in life does not exceed 1.96, the intoxication asymmetry and alcohol consumption distribution indices in the last month and one year exceed the 1.96 limit for the treatment of the distribution as normal (Pett, 2016). For this reason, the findings were processed by non-parametric analysis procedures. 
Tablica 2. Prikaz učestalosti konzumacije alkohola i učestalosti opijanja u životu, u posljednjih godinu dana te u posljednjih mjesec dana

Table 2. Frequency of alcohol consumption and frequency of intoxication in life, in the last year, and in the last month

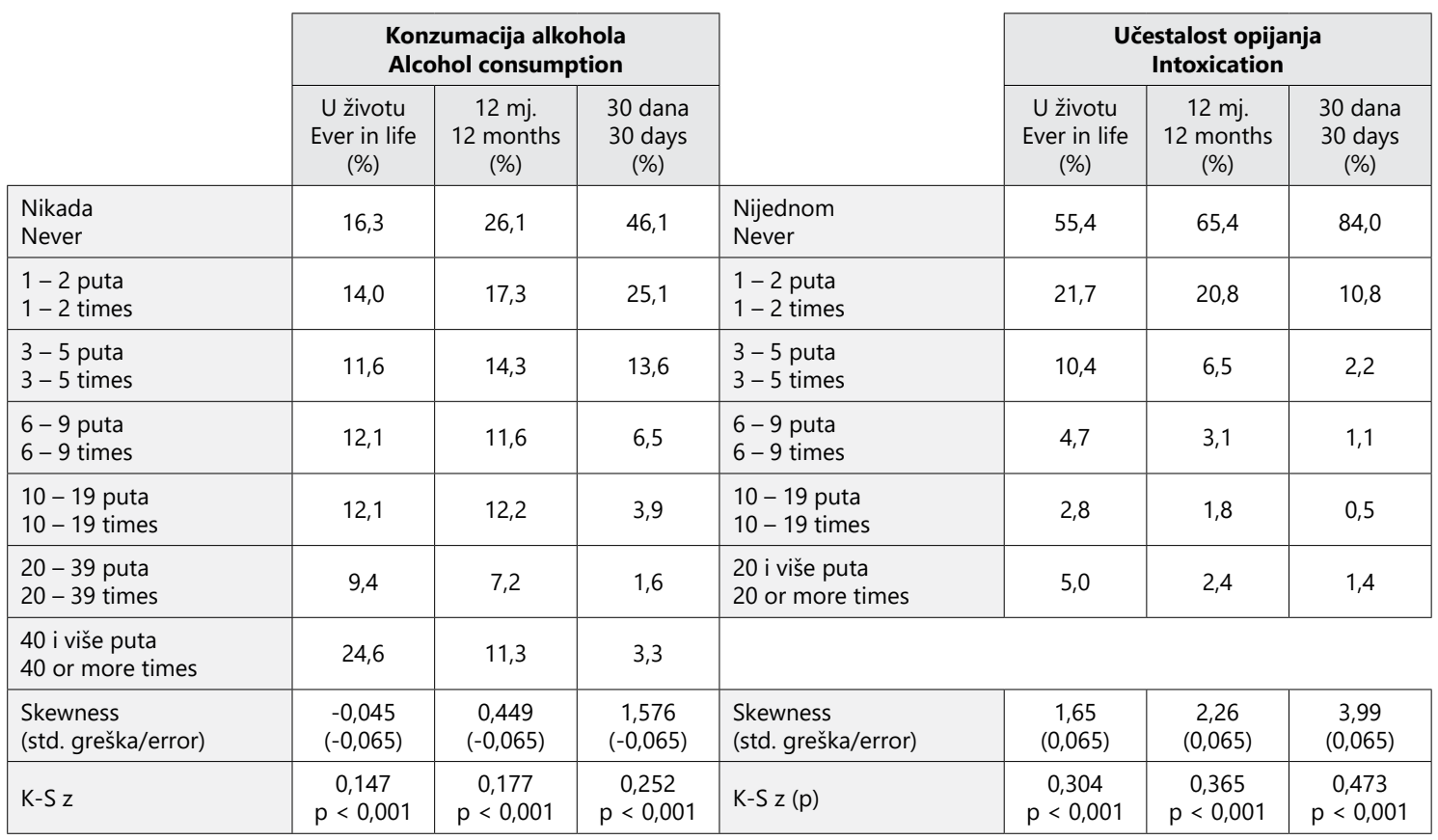

para razreda (pairwise comparations) značajne $(p<0,05)$, a jedine razlike parova koje se nisu pokazale značajnima su one između učenika trećih i četvrtih razreda srednje škole $(p>0,05)$.

Učenici osnovnih škola konzumirali su alkohol značajno manje od učenika srednjih škola, što je utvrđeno i za životnu i godišnju konzumaciju $(p<0,01)$.

Dok se obrazovanje majke nije pokazalo značajnim za učestalost konzumacije alkohola ( $p>0,05)$, očevo obrazovanje pokazalo se značajnim za mjesečnu i životnu konzumaciju alkohola. Pri tome je jedina značajna razlika očeva obrazovanja u mjesečnoj i životnoj konzumaciji alkohola utvrđena među sudionicima čiji očevi imaju završen fakultet i onima čiji su očevi završili višu školu - sudionici čiji su očevi završili fakultet konzumirali su alkohol značajno manje u životu i u posljednjih mjesec dana od onih čiji su očevi završili višu školu.

\section{Description of and Differences in Drinking Habits among Adolescents' in the Split-Dalmatia County with Regard to Socio-Demographic Variables}

The findings presented in Table 2 show that $83.7 \%$ of the students consumed alcoholic drinks at least once in their lives, $73.9 \%$ consumed alcohol in the last year, and $53.9 \%$ consumed alcohol in the last month. $44.6 \%$ of the students were intoxicated at least once in their lives, 34.6\% at least once in the last year, and $16 \%$ at least once in the last month.

The findings in Table 3 show that boys are generally more prone to alcohol consumption than girls.

Higher-grade students consume alcohol significantly more than lower-grade students in all three measured variables (life, one year, one month), with significant differences between 
Tablica 3. Prikaz rezultata razlika u učestalosti konzumiranja alkohola prema rodu (Mann-Whitneyjevu testu), razredu te obrazovanju roditelja (Kruskal-Wallisov test) Table 3. Differences in the frequency of alcohol consumption by gender (Mann-Whitney $U$ test), school grade, and parental education (Kruskal Wallis test)

\begin{tabular}{|c|c|c|c|c|c|c|c|c|c|c|}
\hline & & \multicolumn{3}{|c|}{ U životu/Ever in life } & \multicolumn{3}{|c|}{ Posljednjih 12 mjeseci/Last 12 months } & \multicolumn{3}{|c|}{ Posljednjih 30 dana/Last 30 days } \\
\hline & & Mdn & $M(s d)$ & & Mdn & M (sd) & & Mdn & M (sd) & \\
\hline \multirow{2}{*}{$\begin{array}{c}\text { Rod } \\
\text { Gender }\end{array}$} & $\mathrm{M} / \mathrm{M}$ & 5 & $4,44(2,27)$ & \multirow{2}{*}{$\begin{array}{c}\mathrm{U}=212440,5 \\
\mathrm{p}<0,001\end{array}$} & 3 & $3,59(2,17)$ & \multirow{2}{*}{$\begin{array}{c}U=216911 \\
p<0,001\end{array}$} & 2 & $2,41(1,71)$ & \multirow{2}{*}{$\begin{array}{c}\mathrm{U}=211631,5 \\
\mathrm{p}<0,001\end{array}$} \\
\hline & Ž/F & 4 & $3,90(2,09)$ & & 3 & $3,08(1,88)$ & & 1 & $1,91(1,22)$ & \\
\hline \multirow{5}{*}{$\begin{array}{l}\text { Razred } \\
\text { Grade }\end{array}$} & 8 & 2 & $2,51(1,69)$ & \multirow{5}{*}{$X 2_{(4,1409)}=387344, p<0,001$} & 1 & $1,78(1,22)$ & \multirow{5}{*}{$x^{2}{ }_{(4,1409)}=369380, p<0,001$} & 1 & $1,29(0,91)$ & \multirow{5}{*}{$\begin{array}{c}x_{(4,1409)}=303585 \\
p<0,001\end{array}$} \\
\hline & 1 & 3 & $3,17(1,89)$ & & 2 & $2,54(1,65)$ & & 1 & $1,66(1,19)$ & \\
\hline & 2 & 4 & $4,21(2,06)$ & & 3 & $3,34(1,88)$ & & 2 & $2,21(1,41)$ & \\
\hline & 3 & 6 & $5,32(1,84)$ & & 4 & $4,37(1,96)$ & & 2 & $2,74(1,61)$ & \\
\hline & 4 & 6 & $5,52(1,82)$ & & 5 & $4,52(1,95)$ & & 2 & $2,79(1,67)$ & \\
\hline \multirow{5}{*}{$\begin{array}{l}\text { Obrazovanje oca } \\
\text { Father's education level }\end{array}$} & $\begin{array}{c}\text { OŠ ili manje } \\
\text { Primary school or less }\end{array}$ & 5 & $4,81(2,17)$ & \multirow{5}{*}{$\begin{array}{c}X^{2}(4,1409)=15469, \\
p<0,01\end{array}$} & 3,5 & $3,84(2,35)$ & \multirow{5}{*}{$\begin{array}{c}x^{2}(4,1409)=10143 \\
p<0,05\end{array}$} & 2 & $2,5(1,61)$ & \multirow{5}{*}{$\begin{array}{c}X 2_{(4,1409)}=8233 \\
p>0,05\end{array}$} \\
\hline & $\begin{array}{c}\text { Stručna škola } \\
\text { Vocational school }\end{array}$ & 5 & $4,43(2,36)$ & & 3 & $3,30(2,12)$ & & 2 & $2,14(1,44)$ & \\
\hline & $\begin{array}{c}\text { Srednja škola } \\
\text { Secondary school }\end{array}$ & 4,5 & $4,34(2,12)$ & & 3 & $3,47(1,99)$ & & 2 & $2,17(1,44)$ & \\
\hline & $\begin{array}{l}\text { Viša škola } \\
\text { College }\end{array}$ & 5 & $4,58(2,22)$ & & 3,5 & $3,72(2,04)$ & & 2 & $2,33(1,54)$ & \\
\hline & $\begin{array}{l}\text { Fakultet } \\
\text { University }\end{array}$ & 4 & $3,92(2,13)$ & & 3 & $3,19(1,98)$ & & 2 & $2,03(1,38)$ & \\
\hline \multirow{5}{*}{$\begin{array}{c}\text { Obrazovanje majke } \\
\text { Mother's education level }\end{array}$} & $\begin{array}{c}\text { OŠ ili manje } \\
\text { Primary school or less }\end{array}$ & 4 & $4,28(2,37)$ & \multirow{5}{*}{$\begin{array}{c}X 2_{(4,1409)}=4798 \\
p>0,05\end{array}$} & 3 & $3,56(2,38)$ & \multirow{5}{*}{$\begin{array}{c}x 2_{(4,1409)}=1905 \\
p>0,05\end{array}$} & 2 & $2,60(1,91)$ & \multirow{5}{*}{$\begin{array}{c}\chi^{2} 2_{(4,1409)}=2649 \\
p>0,05\end{array}$} \\
\hline & $\begin{array}{c}\text { Stručna škola } \\
\text { Vocational school }\end{array}$ & 5 & $4,69(2,19)$ & & 3 & $3,26(2,00)$ & & 2 & $2,26(1,56)$ & \\
\hline & $\begin{array}{c}\text { Srednja škola } \\
\text { Secondary school }\end{array}$ & 4 & $4,34(2,13)$ & & 3 & $3,45(1,98)$ & & 2 & $2,14(1,38)$ & \\
\hline & $\begin{array}{l}\text { Viša škola } \\
\text { College }\end{array}$ & 4 & $4,39(2,09)$ & & 3 & $3,50(1,98)$ & & 2 & $2,20(1,46)$ & \\
\hline & $\begin{array}{l}\text { Fakultet } \\
\text { University }\end{array}$ & 4 & $4,12(2,20)$ & & 3 & $3,34(2,03)$ & & 2 & $2,11(1,47)$ & \\
\hline
\end{tabular}


Tablica 4. Prikaz rezultata razlika u učestalosti opijanja u životu prema rodu (MannWhitneyjev test), razredu te obrazovanju roditelja (Kruskal-Wallisov test)

Table 4. Differences in the frequency of intoxication by gender (Mann-Whitney $U$ test), grade, and parental education (Kruskal Wallis test)

\begin{tabular}{|c|c|c|c|c|c|c|c|}
\hline & & \multicolumn{5}{|c|}{$\begin{array}{l}\text { Učestalost opijanja } \\
\text { Frequency of intoxication }\end{array}$} & \\
\hline & & M & Mdn & SD & $\min$ & $\max$ & \\
\hline \multirow{2}{*}{$\begin{array}{l}\text { Rod } \\
\text { Gender }\end{array}$} & $\begin{array}{l}\text { Muško } \\
\text { Male }\end{array}$ & 2,15 & 1,00 & 1,57 & 1,00 & 6,00 & $U=216588,5$ \\
\hline & $\begin{array}{l}\text { Žensko } \\
\text { Female }\end{array}$ & 1,72 & 1,00 & 1,12 & 1,00 & 6,00 & $p<0,001$ \\
\hline \multirow{5}{*}{$\begin{array}{l}\text { Razred } \\
\text { Grade }\end{array}$} & $\begin{array}{l}\text { 8. razred OŠ } \\
\text { 8th grade primary school }\end{array}$ & 1,20 & 1,00 & 0,69 & 1,00 & 6,00 & \multirow{5}{*}{$\begin{array}{c}x^{2}{ }_{(4,1409)}=289898 \\
p<0,001\end{array}$} \\
\hline & $\begin{array}{c}\text { 1. razred SŠ } \\
\text { 1st grade secondary school }\end{array}$ & 1,50 & 1,00 & 1,27 & 1,00 & 6,00 & \\
\hline & $\begin{array}{l}\text { 2. razred SŠ } \\
\text { 2nd grade secondary school }\end{array}$ & 1,91 & 1,00 & 1,28 & 1,00 & 6,00 & \\
\hline & $\begin{array}{l}\text { 3. razred SŠ } \\
\text { 3rd grade secondary school }\end{array}$ & 2,45 & 2,00 & 1,49 & 1,00 & 6,00 & \\
\hline & $\begin{array}{l}\text { 4. razred SŠ } \\
\text { 4th grade secondary school }\end{array}$ & 2,54 & 2,00 & 1,57 & 1,00 & 6,00 & \\
\hline \multirow{5}{*}{$\begin{array}{c}\text { Obrazovanje majke } \\
\text { Mother's education } \\
\text { level }\end{array}$} & $\begin{array}{c}\text { OŠ ili manje } \\
\text { Primary school or less }\end{array}$ & 2,00 & 1,00 & 1,66 & 1,00 & 6,00 & \multirow{5}{*}{$\begin{array}{l}X^{2}(4,1217)=4369 \\
\quad p>0,05\end{array}$} \\
\hline & $\begin{array}{l}\text { Stručna škola } \\
\text { Vocational school }\end{array}$ & 2,12 & 2,00 & 1,31 & 1,00 & 6,00 & \\
\hline & $\begin{array}{l}\text { Srednja škola } \\
\text { Secondary school }\end{array}$ & 1,93 & 1,00 & 1,32 & 1,00 & 6,00 & \\
\hline & $\begin{array}{l}\text { Viša škola } \\
\text { College }\end{array}$ & 2,06 & 1,00 & 1,46 & 1,00 & 6,00 & \\
\hline & $\begin{array}{l}\text { Fakultet } \\
\text { University }\end{array}$ & 1,90 & 1,00 & 1,33 & 1,00 & 6,00 & \\
\hline \multirow{5}{*}{$\begin{array}{c}\text { Obrazovanje oca } \\
\text { Father's education } \\
\text { level }\end{array}$} & $\begin{array}{c}\text { OŠ ili manje } \\
\text { Primary school or less }\end{array}$ & 2,39 & 1,00 & 1,40 & 1,00 & 6,00 & \multirow{5}{*}{$\begin{array}{c}x^{2}(4,1184)=4917 \\
p>0,05\end{array}$} \\
\hline & $\begin{array}{l}\text { Stručna škola } \\
\text { Vocational school }\end{array}$ & 1,95 & 1,00 & 1,40 & 1,00 & 6,00 & \\
\hline & $\begin{array}{l}\text { Srednja škola } \\
\text { Secondary school }\end{array}$ & 1,91 & 1,00 & 1,32 & 1,00 & 6,00 & \\
\hline & $\begin{array}{l}\text { Viša škola } \\
\text { College }\end{array}$ & 2,14 & 2,00 & 1,51 & 1,00 & 6,00 & \\
\hline & $\begin{array}{l}\text { Fakultet } \\
\text { University }\end{array}$ & 1,86 & 1,00 & 1,26 & 1,00 & 6,00 & \\
\hline
\end{tabular}

Legenda: Mdn=medijan; $M=$ aritmetička sredina; $S D=$ standardna devijacija; min=minimum; max=maksimum Legend: $M d n=$ median; $M=$ mean; $s d=$ standard deviation; min=minimum; max= maximum 
Utvrđene su značajne razlike u učestalosti opijanja u životu s obzirom na rod i razred, dok se obrazovanje roditelja nije pokazalo statistički značajnim za učestalost opijanja. Opijanju su skloniji mladići nego djevojke. Pairwise analize pokazuju da su gotovo sve razlike među razredima u učestalosti opijanja značajne ( $\mathrm{p}<$ $0,05)$, izuzev razlike između trećeg i četvrtog razreda srednje škole ( $p>0,05)$, što upućuje na porast učestalosti opijanja u životu s dobi.

\section{Opis navika učestalog pijenja s obzirom na percipirani roditeljski nadzor, očekivanu reakciju roditelja i zadovoljstvo odnosom $s$ roditeljima}

Izdvojena je konzumacija alkohola na mjesečnoj razini ( $n=760 ; 53,9 \%)$ i podijeljena u dvije dihotomne kategorije: Prva kategorija su oni učenici koji su pili od 1 do 5 puta ${ }^{1}$ posljednjih 30 dana $(n=545)$ što se može interpretirati da nisu pili svaki vikend pa su nazvani „povremeni konzumenti alkoholnih pića" i druga kategorija su oni učenici koji su pili šest i više puta u posljednjih mjesec dana $(n=215)$ što se može tumačiti kao konzumacija pića svakim vikendom pa su nazvani „učestali konzumenti alkoholnih pića. Nakon izdvajanja učenika koji su bar jednom pili u posljednjih mjesec dana, udio je povremenih konzumenata $84,7 \%$, a učestalih konzumenata 15,3\%. Utvrđeno je da su adolescenti koji povremeno konzumiraju alkohol procjenjivali manje roditeljskog odobravanja zbog potencijalne konzumacije alkohola nego adolescenti koji su učestalo konzumirali alkohol na mjesečnoj razini (tablica 5). Učestali konzumenti u usporedbi s povremenim konzumentima rjeđe percipiraju da njihovi roditelji imaju jasna pravila ponašanja izvan kuće te da su roditelji upoznati s time gdje i s kime se oni almost every pairwise comparisons $(p<0.05)$, and the only pairwise differences that did not prove significant those between thirdand fourth-grade secondary school students $(p>0.05)$.

Primary school students consumed alcohol significantly less than secondary school students, as found for both life and consumption in one year $(p<0.01)$.

While mother's education level was not found to be significant for the frequency of alcohol consumption ( $p>0.05)$, father's education was found to be significant for the monthly and life consumption of alcohol. The only significant difference regarding father's education in monthly and life alcohol consumption was found between participants whose fathers graduated from university and those whose fathers graduated from college. Participants whose fathers had university education consumed significantly less alcohol in their lives, and in the last month, compared to those whose fathers had college education.

Significant differences in the frequency of intoxication in life with respect to gender and school grade were found, while parental education did not prove statistically significant for the frequency of intoxication. Boys are more prone to getting drunk than girls. Pairwise analyses show that almost all differences between school grades in the frequency of intoxication are significant $(p<0.05)$, except for the difference between the third and fourth grade secondary school ( $p>0.05)$, which indicates an increase in the frequency of intoxication in life with age.

Odgovori na skali od 1 - nikad (isključeno iz analize); 2 - jednom ili dva puta; 3 - od tri do pet puta; 4 - od šest do devet puta; 5 - od deset do 19 puta; 6 - od 20 do 39 puta; 7 - 40 više puta / Answers on a scale from 1- Never (excluded from the analysis); 2- Once or twice; 3- 3 to 5 times; $4-6$ to 9 times; 5- 10 to 19 times; 6 - 20-39 times; 7 - 40 times or more 
druže (1 - Gotovo nikad, 5 - Gotovo uvijek). Nema značajne razlike učestalih konzumenata i povremenih konzumenata u zadovoljstvu odnosima s roditeljima.

\section{Povezanost učestalosti konzumacije alkohola i opijanja s percepcijom roditeljskog nadzora, očekivanih reakcija roditelja i zadovoljstvom odnosa s roditeljima}

Uočava se da su životna učestalost konzumacije alkohola i opijanja nisko povezane sa zadovoljstvom odnosa s roditeljima, roditeljskim nadzorom i pravilima ponašanja izvan kuće (Tablica 6). Učestalost opijanja u životu značajno je povezana s ukupnom učestalosti konzumacije alkohola u životu $(r=0,638)$. Učestalost konzumacije alkohola u životu i u posljednjih 30 dana povezana je s očekivanim reakcijama oca i majke na način da je veća učestalost konzumacije alkohola povezana $\mathrm{s}$ većim odobravanjem opijanja, a jednak odnos zabilježen je među očekivanim roditeljskim reakcijama te učestalosti opijanja u životu. Učestalost je opijanja u posljednjih mjesec dana nisko povezana s očekivanim reakcijama roditelja na opijanje. Očekivana reakcija oca i majke u visokoj su korelaciji $(r=0,738)$. Značajnost iznimno niskih korelacija u Tablici 6 možemo pripisati velikom uzorku (Aggarwal i Ranganathan, 2016).

Da bismo utvrdili zajednički doprinos sociodemografskih varijabli te percepcije roditeljskog nadzora i percepcije potencijalnih reakcija roditelja u predviđanju konzumacije alkohola u životu i u posljednjih mjesec dana, provedene su zasebne regresijske analize za oba kriterija. Unatoč asimetričnim distribucijama konzumacije alkohola u životu i u posljednjih mjesec dana, uvid u P-P plotove i Scatterplotove ne pokazuje velika odstupanja od normaliteta što omogućuje provedbu regresijske analize.

\section{Description of Frequent Drinking Habits with Regard to Perceived Parental Monitoring, Expected Parental Reaction and Satisfaction with Relations with Parents}

Consumption of alcohol on a monthly basis $(n=760 ; 53.9 \%)$ was isolated and divided into two dichotomous categories. The first category included students who had drunk 1-5 times ${ }^{1}$ in the previous 30 days $(n=545)$, which can be interpreted as not drinking every weekend, and this category was called 'occasional consumers of alcoholic drinks'. The second category included students who had drunk 6 or more times in the previous month $(n=215)$, which can be interpreted as drinking every weekend, and this category was called 'frequent consumers of alcoholic drinks'. After identifying students who had drunk at least once in the previous month, the share of occasional consumers was $84.7 \%$, and of frequent consumers $15.3 \%$. Adolescents who occasionally consumed alcohol were found to assess less parental approval of potential alcohol consumption than those who frequently consumed alcohol on a monthly basis (Table 5). In comparison to occasional consumers, frequent consumers less often perceive their parents as having clear rules of conduct outside home, or being familiar with where and who they socialize with (1-Almost never, 5-Almost always). There is no significant difference between frequent and occasional consumers in terms of satisfaction with relations with parents.

\footnotetext{
1 Answers on a scale from 1- Never (excluded from the analysis); 2- Once or twice; 3- 3 to 5 times; $4-6$ to 9 times; 5- 10 to 19 times; 6 - 20-39 times; 7- 40 times or more
} 
Roberta Matković, Ana Petak, Željko Ključević: Odnos navika konzumacije alkohola i percepcije roditeljskih...

Tablica 5. Prikaz rezultata Mann-Whitneyjeva U-testa za ispitivanje razlika adolescenata koji učestalo konzumiraju alkohol i onih koji povremeno konzumiraju alkohol u percepciji roditeljskog nadzora, percepciji potencijalnih reakcija roditelja te zadovoljstvu odnosima s roditeljima

Table 5. Results of the Mann-Whitney U-test examining differences between adolescents who consume alcohol frequently and those who consume alcohol occasionally in the perception of parental monitoring, potential parental reactions and satisfaction with rela tions with parents

\begin{tabular}{|c|c|c|c|c|c|c|}
\hline & & & & & \\
\hline & & $\mathbf{N}$ & M & SD & $\begin{array}{l}\text { Mdn (totalni } \\
\text { raspon/total } \\
\text { range) }\end{array}$ & $\begin{array}{c}\text { Mann-Whitneyjev } \\
\text { test }\end{array}$ \\
\hline \multirow{2}{*}{$\begin{array}{c}\text { Zadovoljstvo odnosom s majkom } \\
\text { Satisfaction with relationship with } \\
\text { mother }\end{array}$} & $\begin{array}{l}\text { Povremeni konzumenti } \\
\text { Occasional consumers }\end{array}$ & 535 & 4,422 & 0,955 & $5(1-5)$ & \multirow{2}{*}{$\begin{array}{c}U=56490,500 \\
p>0,05\end{array}$} \\
\hline & $\begin{array}{l}\text { Učestali konzumenti } \\
\text { Frequent consumers }\end{array}$ & 206 & 4,442 & 0,980 & $5(1-5)$ & \\
\hline \multirow{2}{*}{$\begin{array}{l}\text { Zadovoljstvo odnosom s ocem } \\
\text { Satisfaction with relationship with } \\
\text { father }\end{array}$} & $\begin{array}{l}\text { Povremeni konzumenti } \\
\text { Occasional consumers }\end{array}$ & 532 & 4,329 & 0,958 & $5(1-5)$ & \multirow{2}{*}{$\begin{aligned} U= & 58450,5000 \\
& p>0,05\end{aligned}$} \\
\hline & $\begin{array}{l}\text { Učestali konzumenti } \\
\text { Frequent consumers }\end{array}$ & 205 & 4,400 & 1,027 & $5(1-5)$ & \\
\hline \multirow{2}{*}{$\begin{array}{l}\text { Procjena očekivane majčine } \\
\text { reakcije na opijanje } \\
\text { Assessment of mother's reaction } \\
\text { to intoxication }\end{array}$} & $\begin{array}{l}\text { Povremeni konzumenti } \\
\text { Occasional consumers }\end{array}$ & 504 & 1,887 & 0,816 & $2(1-4)$ & \multirow{2}{*}{$\begin{array}{c}U=54170,500 \\
p<0,01\end{array}$} \\
\hline & $\begin{array}{l}\text { Učestali konzumenti } \\
\text { Frequent consumers }\end{array}$ & 191 & 2,089 & 0,869 & $2(1-4)$ & \\
\hline \multirow{2}{*}{$\begin{array}{l}\text { Procjena očekivane očeve reakcije } \\
\text { na opijanje } \\
\begin{array}{l}\text { Assessment of father's reaction to } \\
\text { intoxication }\end{array}\end{array}$} & $\begin{array}{l}\text { Povremeni konzumenti } \\
\text { Occasional consumers }\end{array}$ & 505 & 1,915 & 0,925 & $2(1--4)$ & \multirow{2}{*}{$\begin{array}{c}U=56470,500 \\
p<0,01\end{array}$} \\
\hline & $\begin{array}{l}\text { Učestali konzumenti } \\
\text { Frequent consumers }\end{array}$ & 195 & 2,179 & 0,997 & $2(1-4)$ & \\
\hline \multirow{2}{*}{$\begin{array}{l}\text { Pravila izvan kuće } \\
\text { Rules outside home }\end{array}$} & $\begin{array}{l}\text { Povremeni konzumenti } \\
\text { Occasional consumers }\end{array}$ & 545 & 3,064 & 1,287 & $3(1-5)$ & \multirow{2}{*}{$\begin{array}{c}U=50765,500 \\
p<0,01\end{array}$} \\
\hline & $\begin{array}{l}\text { Učestali konzumenti } \\
\text { Frequent consumers }\end{array}$ & 215 & 2,753 & 1,322 & $3(1-5)$ & \\
\hline \multirow{2}{*}{$\begin{array}{c}\text { Procjena znanja roditelja gdje se } \\
\text { provode večeri } \\
\text { Perception of parents' knowledge } \\
\text { about where they spend the } \\
\text { evening }\end{array}$} & $\begin{array}{l}\text { Povremeni konzumenti } \\
\text { Occasional consumers }\end{array}$ & 545 & 4,178 & 1,149 & $5(1-5)$ & \multirow{2}{*}{$\begin{array}{c}U=46997,000 \\
p<0,001\end{array}$} \\
\hline & $\begin{array}{l}\text { Učestali konzumenti } \\
\text { Frequent consumers }\end{array}$ & 215 & 3,712 & 1,381 & $4(1-5)$ & \\
\hline \multirow{2}{*}{$\begin{array}{c}\text { Procjena znanja roditelja s kim } \\
\text { provode večeri } \\
\text { Perception of parents' knowledge } \\
\text { about who they spend the } \\
\text { evening with }\end{array}$} & $\begin{array}{l}\text { Povremeni konzumenti } \\
\text { Occasional consumers }\end{array}$ & 545 & 4,101 & 1,224 & $5(1-5)$ & \multirow{2}{*}{$\begin{array}{c}U=48451,000 \\
p<0,001\end{array}$} \\
\hline & $\begin{array}{l}\text { Učestali konzumenti } \\
\text { Frequent consumers }\end{array}$ & 215 & 3,660 & 1,460 & $4(1-5)$ & \\
\hline
\end{tabular}

Legenda: $M d n=$ medijan; $M=$ aritmetička sredina; $S D=$ standardna devijacija Legend: $M d n=$ median; $M=$ mean; $s d=$ standard deviation

Rezultati dviju zasebnih regresijskih analiza (Tablica 7) pokazuju da predviđeni skup prediktora (rod, dob, percepcija roditeljskog nadzora i percepcija potencijalnih reakcija roditelja ) statistički značajno predviđaju konzumaciju alkohola u životu $(F(7,1241)=91,449 ; p<$ $0,000)$ i u posljednjih 30 dana $(F(7,1241)=$ 50,813; $p<0,000$ ). Skup prediktora predviđa $33,7 \%$ varijabiliteta konzumacije alkohola u životu i 22,3\% varijabiliteta konzumacije alkohola u posljednjih mjesec dana. Statistički gledano, od skupa prediktora jedino znanje

\section{Relationship between the Frequency of Alcohol Consumption and Intoxication with Perceived Parental Monitoring, Expected Parental Reactions and Satisfaction with Relations with Parents}

It can be observed that the frequency of alcohol consumption and intoxication in life is in low correlation with satisfaction with relations with parents, parental monitoring, and rules of conduct outside home (Table 6). The frequency of intoxication in life is significantly 
Tablica 6. Prikaz Spearmanova rho koeficijenta korelacije za utvrđivanje veze učestalosti (u životu i u 30 dana) konzumacije alkohola i broja opijanja s percepcijom roditeljskog nadzora, percepcijom očekivanih reakcija roditelja te zadovoljstvom odnosa s roditeljima

Table 6. Spearman's rho correlation coefficient for determining the correlation between the frequency (in life and in 30 days) of alcohol consumption and the number of intoxications with perceived parental monitoring, expected parental reactions and satisfaction with relations with parents

\begin{tabular}{|c|c|c|c|c|c|c|c|c|c|c|c|c|}
\hline & 1 & 2 & 3 & 4 & 5 & 6 & 7 & 8 & 9 & 10 & 11 & 12 \\
\hline 1 - Konzumacija alkohola u posljednjih 30 dana / Alcohol consumption in last 30 days & 1,000 & $0,764^{\star *}$ & $0,599^{\star \star}$ & $0,455^{\star \star}$ & $0,449^{\star \star}$ & $-0,056^{*}$ & $-0,037$ & $0,286^{\star \star}$ & $0,314^{\star \star}$ & $-0,157^{\star \star}$ & $-0,131^{\star *}$ & $-0,064^{*}$ \\
\hline 2 - Konzumacija alkohola u životu / Alcohol consumption ever in life & & 1,000 & $0,638^{\star \star}$ & $0,367^{\star \star}$ & $0,508^{\star \star}$ & $-0,085^{\star *}$ & $-0,069^{*}$ & $0,335^{\star \star}$ & $0,342^{\star \star}$ & $-0,130^{\star *}$ & $-0,103^{* *}$ & $-0,106^{* *}$ \\
\hline 3 - Broj opijanja u životu / Number of intoxications in life & & & 1,000 & $0,592^{* \star}$ & $0,452^{\star \star}$ & $-0,116^{\star \star}$ & $-0,089^{\star \star}$ & $0,321^{\star \star}$ & $0,337^{\star \star}$ & $-0,198^{* \star}$ & $-0,175^{\star \star}$ & $-0,093^{* *}$ \\
\hline 4 - Broj opijanja u posljednjih 30 dana / Number of intoxications in last 30 days & & & & 1,000 & $0,165^{\star \star}$ & $-0,047$ & $-0,015$ & $0,180^{\star \star}$ & $0,186^{\star \star}$ & $-0,166^{* *}$ & $-0,147^{* *}$ & $-0,039$ \\
\hline 5 - Dob / Age & & & & & 1,000 & $-0,023$ & $-0,049$ & $0,253^{\star \star}$ & $0,209^{\star \star}$ & $-0,071^{* *}$ & $-0,069^{* *}$ & $-0,117^{* *}$ \\
\hline 6 - Zadovoljstvo odnosom s majkom / Satisfaction with relationship with mother & & & & & & 1,000 & $0,695^{* \star}$ & $-0,069^{*}$ & $-0,041$ & $0,182^{\star *}$ & $0,167^{\star \star}$ & $0,058^{*}$ \\
\hline 7 - Zadovoljstvo odnosom s ocem / Satisfaction with relationship with father & & & & & & & 1,000 & $-0,073^{*}$ & $-0,014$ & $0,146^{* *}$ & $0,128^{* *}$ & 0,035 \\
\hline 8 - Procjena reakcije majke na opijanje / Assessment of mother's reaction to intoxication & & & & & & & & 1,000 & $0,738^{\star *}$ & $-0,102^{\star \star}$ & $-0,123^{\star *}$ & $-0,203^{* *}$ \\
\hline 9 - Procjena reakcije oca na opijanje / Assessment of father's reaction to intoxication & & & & & & & & & 1,000 & $-0,092^{\star \star}$ & $-0,132^{\star \star}$ & $-0,185^{\star *}$ \\
\hline $\begin{array}{l}10 \text { - Percepcija znanja roditelja o tome gdje se provodi večer / Perception of parents' knowledge about where } \\
\text { they spend the evening }\end{array}$ & & & & & & & & & & 1,000 & $0,777^{\star \star}$ & $0,307^{\star *}$ \\
\hline $\begin{array}{l}11 \text { - Percepcija znanja roditelja o tome s kime se provodi večer / Perception of parents' knowledge about who } \\
\text { they spend the evening with }\end{array}$ & & & & & & & & & & & 1,000 & $0,306^{\star *}$ \\
\hline 12 - Postojanje pravila izvan kuće / Existence of rules outside home & & & & & & & & & & & & 1,000 \\
\hline
\end{tabular}

Legenda/Legend: ${ }^{*} p<0,01 ;{ }^{*} p<0,05$ 
Roberta Matković, Ana Petak, Željko Ključević: Relationship Between Alcohol Consumption Habits and the...

Tablica 7. Prikaz rezultata dviju zasebnih regresijskih analiza sa sociodemografskim varijablama, roditeljskim nadzorom te očekivanim reakcijama roditelja kao prediktorima za kriterij učestalosti konzumacije alkohola u životu i kriterij konzumacije alkohola u posljednjih mjesec dana

Table 7. Results of two separate regression analyses with socio-demographic variables, parental monitoring and expected parental reactions as predictors for the criterion of frequency of alcohol consumption in life and the criterion of alcohol consumption in the last month

\begin{tabular}{|c|c|c|c|c|c|c|}
\hline & \multicolumn{3}{|c|}{$\begin{array}{l}\text { Konzumacija alkohola u životu } \\
\text { Alcohol consumption ever in life }\end{array}$} & \multicolumn{3}{|c|}{$\begin{array}{c}\text { Konzumacija alkohola u proteklih } \\
\text { mjesec dana } \\
\text { Alcohol consumption in last month }\end{array}$} \\
\hline & Beta & $t$ & Sig. & Beta & $t$ & Sig. \\
\hline (Constant) & & $-10,876$ & 0,000 & & $-6,282$ & 0,000 \\
\hline Rod / Gender & $-0,093$ & $-3,911$ & 0,000 & $-0,120$ & $-4,673$ & 0,000 \\
\hline Dob / Age & 0,448 & 18,797 & 0,000 & 0,340 & 13,139 & 0,000 \\
\hline $\begin{array}{l}\text { Procjena očekivane reakcije } \\
\text { majke na opijanje / Assessment of mother's reaction } \\
\text { to intoxication }\end{array}$ & 0,091 & 2,654 & 0,008 & 0,061 & 1,640 & 0,101 \\
\hline $\begin{array}{l}\text { Procjena očekivane reakcije } \\
\text { oca na opijanje / Assessment of father's reaction to } \\
\text { intoxication }\end{array}$ & 0,183 & 5,388 & 0,000 & 0,142 & 3,838 & 0,000 \\
\hline $\begin{array}{l}\text { Procjena znanja roditelja gdje se provode večeri } \\
\text { / Assessment of parents' knowledge about where } \\
\text { they spend the evening }\end{array}$ & $-0,071$ & $-1,982$ & 0,048 & $-0,108$ & $-2,777$ & 0,006 \\
\hline $\begin{array}{l}\text { Procjena znanja roditelja s kime se provode večeri / } \\
\text { Assessment of parents' knowledge about who they } \\
\text { spend the evening with }\end{array}$ & 0,036 & 1,012 & 0,312 & 0,002 & 0,042 & 0,967 \\
\hline \multirow[t]{2}{*}{ Pravila izvan kuće / Rules outside home } & 0,007 & 0,269 & 0,788 & 0,024 & 0,891 & 0,373 \\
\hline & \multicolumn{3}{|c|}{$\begin{array}{c}R=0,583 ; R^{2}=0,340 ; \\
\text { Korigirani/Corrected } R^{2}=0,337\end{array}$} & \multicolumn{3}{|c|}{$\begin{array}{c}R=0,472 ; R^{2}=0,223 \\
\text { Korigirani/Corrected } R^{2}=0,218\end{array}$} \\
\hline
\end{tabular}

roditelja s kime adolescenti provode večeri te postojanje pravila ponašanja izvan kuće ne doprinose značajno količini alkohola konzumiranog u životu. Na razini mjesečne konzumacije alkohola, značajan doprinos kriteriju utvrđen je za sve prediktore osim za znanje roditelja s kime adolescent provodi večeri, postojanje pravila izvan kuće i percipirane reakcije majke na opijanje. Kao najbolji prediktor konzumacije alkohola ističe se dob.

Rezultati dviju zasebnih regresijskih analiza (Tablica 8) pokazuju da predviđeni skup prediktora (rod, dob, percepcija roditeljskog nadzora, percepcija potencijalnih reakcija roditelja, konzumacija alkohola u zadnjih 30 dana) statistički značajno predviđaju broj opijanja u životu ( $F$ $(8,1240)=106,431 ; p<0,000)$ i u posljednjih 30 dana $(F(8,1240)=51,023 ; p<0,000)$. Skup prediktora predviđa $40,3 \%$ varijabiliteta correlated with the total frequency of alcohol consumption in life $(R=0.638)$. The frequency of alcohol consumption in life and in the last 30 days is correlated to father's and mother's expected reactions, in such a way that a higher frequency of alcohol consumption is correlated to more approval of drinking, and the same correlation was observed between expected parental reactions and the frequency of intoxication in life. The frequency of intoxication in the last month is in low correlation with expected parental reactions to intoxication. Father's and mother's expected reactions are highly correlated $(R=0.738)$. The significance of exceptionally low correlations in Table 6 can be attributed to the large sample (Aggarwal and Ranganathan, 2016).

To determine the joint contribution of socio-demographic variables and the perception 
Tablica 8. Prikaz rezultata dviju zasebnih regresijskih analiza sa sociodemografskim varijablama, roditeljskim nadzorom, očekivanim reakcijama roditelja i konzumacijom alkohola na mjesečnoj razini kao prediktorima za kriterije učestalosti opijanja u životu i u posljednjih mjesec dana

Table 8. Results of two separate regression analyses with socio-demographic variables, parental monitoring, expected parental reactions, and consumption of alcohol on a monthly basis as predictors for the criteria of frequency of intoxication in life and in the last month

\begin{tabular}{|c|c|c|c|c|c|c|}
\hline & \multicolumn{3}{|c|}{$\begin{array}{l}\text { Učestalost opijanja u životu } \\
\text { Frequency of intoxication in life }\end{array}$} & \multicolumn{3}{|c|}{$\begin{array}{l}\text { Učestalost opijanja u proteklih } \\
\text { mjesec dana } \\
\text { Frequency of intoxication in last } \\
\text { month }\end{array}$} \\
\hline & Beta & $\mathrm{t}$ & Sig. & Beta & $\mathrm{t}$ & Sig. \\
\hline (Constant) & & $-2,864$ & 0,004 & & 6,124 & 0,000 \\
\hline Rod / Gender & $-0,057$ & $-2,500$ & 0,013 & $-0,008$ & $-0,310$ & 0,757 \\
\hline Dob / Age & 0,155 & 6,406 & 0,000 & $-0,054$ & $-2,002$ & 0,046 \\
\hline $\begin{array}{l}\text { Procjena očekivane reakcije } \\
\text { majke na opijanje / Assessment of mother's reaction } \\
\text { to intoxication }\end{array}$ & 0,081 & 2,508 & 0,012 & 0,085 & 2,316 & 0,021 \\
\hline $\begin{array}{l}\text { Procjena očekivane reakcije } \\
\text { oca na opijanje / Assessment of father's reaction to } \\
\text { intoxication }\end{array}$ & 0,117 & 3,607 & 0,000 & $-0,017$ & $-0,456$ & 0,649 \\
\hline $\begin{array}{l}\text { Procjena znanja roditelja gdje se provode večeri } \\
\text { / Assessment of parents' knowledge about where } \\
\text { they spend the evening }\end{array}$ & $-0,014$ & $-0,422$ & 0,673 & $-0,095$ & $-2,472$ & 0,014 \\
\hline $\begin{array}{l}\text { Procjena znanja roditelja s kime se provode večeri / } \\
\text { Assessment of parents' knowledge about who they } \\
\text { spend the evening with }\end{array}$ & $-0,087$ & $-2,564$ & 0,010 & $-0,045$ & $-1,183$ & 0,237 \\
\hline Pravila izvan kuće / Rules outside home & 0,014 & 0,599 & 0,549 & 0,039 & 1,477 & 0,140 \\
\hline \multirow[t]{2}{*}{$\begin{array}{l}\text { Konzumacija alkohola u zadnjih } 30 \text { dana / Alcohol } \\
\text { consumption in last } 30 \text { days }\end{array}$} & 0,440 & 17,725 & 0,000 & 0,459 & 16,411 & 0,000 \\
\hline & \multicolumn{3}{|c|}{$\begin{array}{c}\quad R=0,638 ; R^{2}=0,407 ; \\
\text { Korigirani/Corrected } R^{2}=0,403\end{array}$} & \multicolumn{3}{|c|}{$\begin{array}{c}R=0,498 ; R^{2}=0,248 ; \\
\text { Korigirani/Corrected } R^{2}=0,243\end{array}$} \\
\hline
\end{tabular}

učestalosti opijanja u životu i 24,3\% varijabiliteta učestalosti opijanja u posljednjih mjesec dana. Statistički gledano, od skupa prediktora jedino znanje roditelja s kime adolescenti provode večeri te postojanje pravila ponašanja izvan kuće ne doprinose značajno učestalosti opijanja u životu. Na razini mjesečnog broja opijanja, značajan doprinos kriteriju utvrđen je za dob, procjenu očekivane reakcije majke, procjenu znanja roditelja o tome gdje se provode večeri i konzumaciju alkohola u životu. Kao najbolji prediktor učestalosti opijanja za oba kriterija ističe se procjena konzumacije alkohola u zadnjih 30 dana. Konzumacija alkohola u proteklih 30 dana uvedena je kao prediktor $u$ analizu radi umjerene povezanosti s kriterijem učestalosti opijanja u životu i u proteklih mjesec dana, dok je životna konzumacija alkohola također of parental monitoring and parents' potential reactions in predicting the consumption of alcohol in life and in the last month, separate regression analyses were carried out for both criteria. Despite the asymmetric distributions of alcohol consumption in life and in the last month, insight into P-P plots and scatter plots shows no major deviations from normal, which allows carrying out a regression analysis.

Results of the two separate regression analyses (Table 7) show that the envisaged set of predictors (gender, age, perceived parental monitoring, perceived potential parental reactions) statistically significantly predict alcohol consumption in life $(F(7.1241)=91.449 ; p<0.000)$ and in the last 30 days $(F(7.1241)=50.813$; $\mathrm{p}<0.000$ ). The set of predictors predicts $33.7 \%$ variability of alcohol consumption in life, and 
Roberta Matković, Ana Petak, Željko Ključević: Odnos navika konzumacije alkohola i percepcije roditeljskih...

povezana s kriterijima, no povezanost s učestalosti opijanja u 30 dana je niska (Tablica 6).

\section{RASPRAVA}

\section{Navike konzumacije alkohola među adolescentima Splitsko-dalmatinske županije te usporedba s obzirom na sociodemografska obilježja}

S obzirom na polazno istraživačko pitanje o navikama konzumacije alkohola među adolescentima, pokazalo se da je $83,7 \%$ učenika iz uzorka barem jednom u životu konzumiralo alkoholna pića, 73,9\% učenika konzumiralo je alkohol u posljednjih godinu dana, a 53,9\% učenika u posljednjih mjesec dana. Istraživanja u Hrvatskoj koja opisuju konzumaciju alkohola kod djece i adolescenata uglavnom su provedena na razini škole ili grada te obuhvaćaju ispitanike različite dobne strukture, stoga je zbog rezultata na reprezentativnom nacionalnom uzorku kao referentni okvir odabrano ESPAD istraživanje. Podatci iz 2019. godine (ESPAD Group, 2020a, 2020b) pokazuju da je čak 90\% petnaestogodišnjaka u Hrvatskoj barem jednom pilo, što je iznad europskog prosjeka (79\%), a u usporedbi s drugim europskim zemljama jedine više životne prevalencije zabilježene su u Češkoj (95\%), Danskoj (92\%), Mađarskoj i Slovačkoj (91\%). Njemačka bilježi istu prevalenciju konzumacije alkohola kao i Hrvatska. Konzumacija alkohola u posljednjih 30 dana može se tumačiti kao trenutna konzumacija koja je zabilježena kod 58\% petnaestogodišnjaka u Hrvatskoj (ESPAD Group, 2020a, 2020b), s tim da od ukupnog broja ispitanika njih 39\% konzumira alkohol povremeno, a 19\% učestalo. U usporedbi s ostalim zemljama, Hrvatska je na visokome osmom mjestu po konzumaciji alkohola u posljednjih mjesec dana. Prosječno, svaki drugi adolescent na europskom uzorku
$22.3 \%$ variability of alcohol consumption in the last month. Statistically speaking, of the set of predictors, only parents' knowledge about who adolescents spend their evenings with, and the existence of rules of conduct outside home do not significantly contribute to the amount of alcohol consumed in life. At the level of monthly alcohol consumption, significant contribution to the criterion was established for all predictors except for parents' knowledge about who adolescents spend their evenings with, the existence of rules outside home, and perceived reaction of the mother to drinking. The best predictor of alcohol consumption seems to be age.

Results of the two separate regression analyses (Table 8) show that the envisaged set of predictors (gender, age, perceived parental monitoring, perceived potential parental reactions, alcohol consumption in the last 30 days) statistically significantly predict the number of intoxications in life $(F(8.1240)=106.431 ; p<$ $0.000)$ and in the last 30 days $(F(8.1240)=51.023$; $p<0.000$ ). The set of predictors predicts $40.3 \%$ variability in the frequency of drinking in life, and $24.3 \%$ variability of the frequency of intoxication in the last month. Statistically speaking, of the set of predictors, only parents' knowledge about who adolescents spend their evenings with, and the existence of rules of conduct outside home do not significantly contribute to the frequency of intoxication in life. At the level of the monthly number of intoxications, significant contribution to the criterion was established for age, perceived reaction of the mother, assessment of parents' knowledge about where they spend the evenings, and the consumption of alcohol in life. The best predictor of the frequency of intoxication for both criteria seems to be the estimate of alcohol consumption in the last 30 days. Alcohol consumption in the last 30 days was introduced as a predictor in the analysis due to its moderate correlation with the criterion 
trenutno konzumira alkohol, s tim da je takvo ponašanje najzastupljenije u Danskoj (74\%), potom slijede Njemačka, Češka, Austrija, Grčka, Mađarska i Italija (ESPAD Group, 2020a, 2020b). Uz oprez zbog nemogućnosti testiranja statističke značajnosti, iz navedenih podataka može se uočiti trend više konzumacije alkohola među mladima u Splitsko-dalmatinskoj županiji u odnosu na europski prosjek, no niže u odnosu na hrvatski prosjek.

Manje od polovice sudionika (44,6\%) iskusilo je stanje opijenosti barem jednom u životu te $16 \%$ u posljednjih 30 dana, što je u skladu $\mathrm{s}$ ESPAD-ovim podatcima (ESPAD Group, 2020a, 2020b) na hrvatskom prosjeku (životna prevalencija pijanstva 43\%; pijanstvo u posljednjih 30 dana 15\%) no učestalije od europskog prosjeka (životna prevalencija pijanstva 36\%; pijanstvo u posljednjih 30 dana 13\%). Zabrinjavajuća je činjenica da je unatoč očekivano pozitivno asimetričnoj raspodjeli učestalosti opijanja u svim kategorijama razreda uočeno postizanje maksimalnog rezultata koji upućuje na učestalost opijanja 20 ili više puta u životu.

Utvrđena učestalija konzumacija alkohola i učestalija opijenost kod mladića u odnosnu na djevojke u skladu je s domaćim i europskim istraživanjima (Bouillet i Čale-Mratović, 2007; Glavak Tkalić, Miletić i Sakoman, 2013; Haug, Schaub, Salis Gross, John i Meyer, 2013; Kalebić Maglica i Martinac Dorčić, 2015; Kuzman i Katalinić, 2005; Ljubotina i Galić, 2002; NolenHoeksema, 2004; Sakoman, Kuzman, i RabotegŠarić, 1999; Piko, 2006; Windle, 2003). Prema hrvatskim podatcima istraživanja na općoj populaciji muškarci piju i opijaju se češće nego žene (Štimac Grbić i Glavak Tkalić, 2020). Recentni podatci za petnaestogodišnjake u hrvatskoj populaciji bilježe učestaliju konzumaciju alkohola zadnjih 30 dana (61\% mladići i 54\% djevojke) te učestalije opijanje u svim trima vremenskim intervalima kod mladića (u životu: of the frequency of intoxication in life and in the last month, while alcohol consumption in life is also correlated to the criteria, though the correlation with the frequency of intoxication in 30 days is low (Table 6).

\section{DISCUSSION}

\section{Alcohol Consumption Habits among Adolescents in the Split-Dalmatia County and Comparison with Regard to Socio-Demographic Characteristics}

With regard to the initial research question about alcohol drinking habits among adolescents, the findings show that $83.7 \%$ of the sampled students consumed alcoholic drinks at least once in their lives, $73.9 \%$ consumed alcohol in the previous year, and $53.9 \%$ consumed alcohol in the previous month. As studies describing alcohol consumption in children and adolescents in Croatia were mostly conducted at school or city level and covered respondents of different age structures, the ESPAD research was chosen as the reference frame for results on a representative national sample. The 2019 data (ESPAD Group, 2020a, 2020b) show that as much as $90 \%$ of the 15 -year-olds in Croatia drank alcohol at least once, which is above the European average (79\%). Compared to other European countries, the only higher prevalence was recorded in the Czech Republic (95\%), Denmark (92\%), Hungary, and Slovakia (91\%). Germany registered the same prevalence of alcohol consumption as Croatia. Alcohol consumption in the last 30 days can be interpreted as current consumption, and was recorded in $58 \%$ of the 15 -year-olds in Croatia (ESPAD Group, 2020a, 2020b), with 39\% of the total number of respondents drinking alcohol occasionally, and $19 \%$ frequently. Compared to other countries, Croatia ranks eighth in terms 
47\% mladići i 39\% djevojke; zadnjih 12 mjeseci: 38\% mladići i 30\% djevojke; zadnjih 30 dana: 16\% mladići i 13\% djevojke) (ESPAD Group, 2020a). Podatci hospitalizacije adolescenata i mlađih punoljetnika pokazuju da je od 2013. do 2018. godine bilo hospitalizirano značajnije više muških pacijenata zbog alkoholne intoksikacije u Općoj bolnici Karlovac na Odjelu pedijatrije, Odjelu psihijatrije te Objedinjenom hitnom bolničkom prijamu (Spudić i Kosić, 2020). Witt (2007) smatra da ne postoje razlike po rodu u konzumaciji alkohola kod adolescenata, dok Dawson (1996) smatra da se obrasci ponašanja mijenjaju nakon adolescencije na način da muškarci piju učestalije i prekomjernije od žena, stoga su nalazi rodnih razlika u konzumaciji alkohola nedosljedni. Muškarci su tijekom povijesti konzumacijom alkohola dokazivali i odražavali moć i promiskuitetno ponašanje. Rizična ponašanja bila su društveno tolerantnija za muškarce dok se od žena očekivalo odgovorno ponašanje (Obot i Room, 2005). Promjene u društvenim odnosima, emancipacija žena i ravnopravnost spolova utjecale su na tradicionalne rodne uloge, na smanjivanje rodne razlike u konzumaciji alkohola, pa čak i na učestaliju konzumaciju alkohola kod žena (Pirkle i Richter, 2006). Moguće je da na rodnu razliku u konzumaciji alkohola više utječu neki drugi čimbenici nego rodno određenje, poput povišenih razina anksioznosti i depresivnosti kod žena (Johannessen, Andersson, Bjørngaard i Pape, 2017), kvalitete odnosa s roditeljima i razine samopoštovanja Kumpfer, Smith i Summerhays 2008; Sale, Sambrano, Springer i Turner, 2003).

Utvrđeno je da su učenici viših razreda više puta u životu konzumirali alkohol nego učenici nižih razreda, no razlika na toj varijabli može se pripisati dobi, odnosno činjenici da su učenici viših razreda imali i više prilika u životu konzumirati alkohol od mlađih učenika. $U$ istraživanju provedenom u Sisku utvrđeno je of alcohol consumption in the past month. On average, every other adolescent in the European sample currently drinks alcohol, with such behavior being the most common in Denmark (74\%), followed by Germany, the Czech Republic, Austria, Greece, Hungary, and Italy (ESPAD Group, 2020a, 2020b). Given caution due to the inability to test statistical significance, the above data show a trend of higher alcohol consumption among young people in the SplitDalmatia County compared to the European average, but lower than the Croatian average.

Less than half of the participants (44.6\%) experienced a state of intoxication at least once in their lives, and $16 \%$ did in the last 30 days, which is consistent with ESPAD data (ESPAD Group, 2020a, 2020b) for the Croatian average (life prevalence of intoxication 43\%; intoxication in the last 30 days 15\%), but more frequent than the European average (life prevalence of intoxication $36 \%$; intoxication in the last 30 days $13 \%$ ). A worrying fact is that, despite the expected positively asymmetrical distribution of the frequency of intoxication in all categories, a maximum result indicating the frequency of intoxication of 20 or more times in life was observed.

More frequent alcohol consumption and more frequent intoxication established in boys in relation to girls is in line with Croatian and European research (Bouillet and Čale-Mratovic, 2007; Glavak Tkalić, Miletić and Sakoman, 2013; Haug, Schaub, Salis Gross, John and Meyer, 2006; Kalebić Maglica and Martinac Dolčić, 2015; Kuzman and Katalinić, 2005; Ljubotina and Galić; Nolen-Hoeksema, 2004; Sakoman, Kuzman, and Raboteg-Šarić, 1999; Piko, 2006; Windle, 2003). According to Croatian research data on the general population, men drink and get drunk more often than women (Štimac Grbić and Glavak Tkalić, 2020). Recent data for 15-year-olds in the Croatian population 
da je $65 \%$ učenika prvih i $83 \%$ učenika četvrtih razreda srednje škole pilo alkohol (Domitrović i Županić, 2016). Učenici počinju s konzumacijom alkohola još u osnovnoj školi (Gajnik i Koražija, 2008; Samardžić i sur., 2011), najčešće u dobi od 13 i 14 godina (Kokkevi i sur., 2007) te se udio onih koji konzumiraju alkohol povećava s godinama (Currie i sur., 2012), što je nalaz i ovog istraživanja.

Obrazovanje majke nije se pokazalo značajnim za učestalost konzumacije alkohola, no sudionici čiji su očevi završili fakultet konzumirali su alkohol značajno manje u životu i u posljednjih mjesec dana od onih čiji su očevi završili višu školu. Izuzev spomenute razlike između dviju razina očeva obrazovanja (fakultetskog $i$ više škole), nisu utvrđene razlike u učestalosti konzumacije alkohola kod adolescenata s obzirom na ostale razine obrazovanja roditelja, kao ni razlike u učestalosti opijanja. To nije $u$ skladu s dosadašnjim istraživanjima (Bjarnason, 2000; Tunistra, Groothof i Van den Huevel 1998; Vrselja i Glavak-Tkalić, 2011) koja povezuju obrazovanje roditelja s konzumacijom sredstava ovisnosti kod djece, unatoč nejasnu smjeru povezanosti - dok neke studije nailaze na veću sklonost rizičnom ponašanju kod djece obrazovanijih roditelja (npr. Vrselja i Glavak-Tkalić, 2011), druge utvrđuju manju sklonost rizičnim ponašanjima s porastom obrazovanja roditelja (npr. Melotti i sur., 2013; Torikka i sur., 2017).

Rezultati dobiveni na razini očeva obrazovanja djelomično su u skladu s idejom da obrazovaniji roditelji potiču zdravija ponašanja te imaju više resursa za superviziju djece (Melotti i sur., 2013). Moguće da je fakultetsko obrazovanje oca potencijalni zaštitni čimbenik za konzumaciju alkohola kod adolescenata. Novija istraživanja pokazuju odmak od tradicionalne uloge oca kao hranitelja i autoriteta te trend većeg uključivanja očeva u odgoj i život djece (Cvrtnjak i Miljević-Riđički, 2015). Očevi s note more frequent alcohol consumption in the last 30 days ( $61 \%$ in boys and $54 \%$ in girls) and more frequent intoxication in all three time intervals in boys (life: $47 \%$ of boys and $39 \%$ of girls; last 12 months: $38 \%$ of boys and $30 \%$ of girls; last 30 days: $16 \%$ of boys and $13 \%$ of girls) (ESPAD Group, 2020a). Data on the hospitalization of adolescents and young adults show that, from 2013 to 2018, more male patients were hospitalized for alcohol intoxication at the Pediatric Department, Psychiatric Department, and the Emergency Service of the Karlovac General Hospital (Spudić and Kosić, 2020). Witt (2007) suggests that there is no gender difference in alcohol consumption in adolescents, while Dawson (1996) believes that the patterns of behavior change after adolescence so that men drink more frequently and excessively than women, making findings on gender differences in alcohol consumption inconsistent. Throughout history, men have consumed alcohol to prove and reflect power and promiscuous behavior. Risk behaviors were more socially acceptable for men, while women were expected to behave responsibly (Obot and Room, 2005). Changes in social relations, emancipation of women and gender equality have influenced traditional gender roles, decreasing gender differences in alcohol consumption, and even making alcohol consumption in women more frequent (Pirkle and Richter, 2006). It is possible that differences in alcohol consumption between men and women are more influenced by factors other than gender determination, such as increased levels of anxiety and depression in women (Johannessen, Andersson, Bjørngaard and Pope, 2017), quality of relations with parents, and levels of self-esteem (Kumpfer, Smith and Summerhays 2008; Sale, Sambrano, Springer and Turner, 2003).

It was found that senior-grade students had consumed alcohol more times in their lives than junior-grade students, but the difference 
višim obrazovanjem ostvaruju više rezultate na skalama roditeljske uključenosti i pozitivnoga roditeljstva od očeva s nižom obrazovnom razinom te se koriste raznolikijim odgojnim i disciplinskim tehnikama (Hadjicharalambous, 2021). Obrazovanje razvija kompetencije na mnogim razinama te posljedično ima učinke za zdravlje (Ross i Mirowsky, 2011). Visoka razina obrazovanja povećava osjećaj osobne kontrole (Mirowsky i Ross, 2003) što doprinosi odluci o zdravim stilovima života. U usporedbi s ljudima koji se osjećaju nemoćno, ljudi s osjećajem osobne kontrole vjerojatnije će prestati pušiti, početi vježbati i umjereno konzumirati alkohol (Mirowsky i Ross, 1998), a roditeljska konzumacija alkohola rizičan je čimbenik za konzumaciju kod adolescenata (Smit, Voogt, Otten, Kleinjan i Kuntsche, 2019; Waddell, Blake, Sternberg, Ruof i Chassin, 2020). Pokazalo se da je izloženost očevoj konzumaciji alkohola u djetinjstvu imala učinak na očekivanja adolescenata od konzumacije alkohola, no izloženost majčinoj konzumaciji nije imala takve učinke (Smith i sur., 2019).

\section{Odnos navika konzumiranja alkohola te percepcije nadzora, odnosa s roditeljima i očekivane roditeljske reakcije na konzumaciju}

Adolescenti koji smatraju da njihovi roditelji odobravaju pijenje u većoj mjeri su skloniji pijenju od onih koji smatraju da njihovi roditelji takva ponašanja ne bi odobrili. Zanimljivo je da su očekivana reakcija oca i majke u visokoj korelaciji $(r=0,738)$, što može upućivati na visoko slaganje roditeljskih stavova prema konzumaciji alkohola. Odnos percipiranih roditeljskih stavova prema alkoholu s učestalosti konzumacije u skladu je s očekivanjima (Farrington, 1995; Mihić i sur., 2013). Izostanak roditeljskog neodobravanja antisocijalnog ponašanja djece te manjak discipline vezane uz upuštanje $u$ rizična ponašanja može doprinijeti izgradnji in this variable can be attributed to age, i.e. the fact that senior-grade students had had more opportunities to consume alcohol than younger students. A survey conducted in Sisak found that $65 \%$ of first-grade and $83 \%$ of fourth-grade students had drunk alcohol (Domitrović and Županić, 2016). Students start drinking alcohol in primary school (Gajnik and Koražija, 2008; Samardžić et al., 2011), usually at the age of 13 to 14 (Kokkevi et al., 2007), and the share of those who drink alcohol increases with age (Currie et al., 2012), which corresponds with findings of this research.

Mother's education level did not prove significant for the frequency of alcohol consumption, but participants whose fathers had graduated from university consumed alcohol significantly less in their lives and in the last month than those whose fathers had only finished secondary school. Apart from the difference between the two levels of father's education (university and college), no differences were established in the frequency of alcohol consumption, or frequency of intoxication, in adolescents with regard to other levels of parental education. This is not in line with research carried out so far (Bjarnason, 2000; Tunistra, Groothof and Van den Huevel 1998; Vrselja and Glavak-Tkalić, 2011) linking parental education with the consumption of addictive substances in children, despite the unclear relationship - while some studies find a greater predisposition to risk behavior in children of educated parents (e.g. Vrselja and Glavak-Tkalić, 2011), others identify less predisposition to risk behavior with an increase in parental education (e.g. Melotti et al., 2013; Torikka et al., 2017).

The results obtained at the level of paternal education are partially in line with the idea that more educated parents encourage healthier behaviors and have more resources for child monitoring (Melotti et al., 2013). It is possible 
neadekvatna vrijednosnog sustava adolescenata u kojem će oni biti skloniji konzumaciji alkohola (Farrington, 1995; Ferić-Šlehan, 2008).

Dihotomiziranjem varijable konzumacije alkohola na mjesečnoj razini na povremene i učestale konzumente pokazalo se da u grupi učestalih konzumenata alkohola roditelji rjeđe imaju jasna pravila ponašanja izvan kuće te su rjeđe upoznati s tim gdje su im djeca i s kim se djeca druže. Obiteljska pravila i informiranost roditelja o adolescentovim aktivnostima povezani su s konzumacijom sredstava ovisnosti (Kandel i Andrews, 1987; Ennett, Bauman, Foshee, Pemberton i Hicks, 2001), a uz kvalitetu komunikacije i djetetovo povjerenje u roditeljsku informiranost umanjuje vjerojatnost adolescentova uključivanja u neprimjerena ponašanja (Mihić i sur., 2013).

lako je zadovoljstvo odnosom s roditeljima važan zaštitni čimbenik (Hawkins i sur., 1992), u ovom istraživanju konzumacija alkohola kod adolescenata nije se pokazala povezanom sa zadovoljstvom odnosa s roditeljima. Takvi rezultati su u skladu sa zaključcima preglednog rada o učincima odnosa roditelja i djeteta na konzumaciju alkohola kod mladih (Visser, Winter i Reijneveld, 2012). Većina studija (njih 16) ne nalazi vezu konzumacije alkohola i odnosa s roditeljima, sedam studija nalazi tu vezu za pojedine subgrupe (npr. samo mladiće ili samo djevojke), a samo pet studija nalazi da je lošiji odnos s roditeljima povezan s višom konzumacijom alkohola (Visser i sur., 2012). Nedosljednost istraživačkih nalaza Visser i suradnici (2012) objašnjavaju različitim operacionalizacijama odnosa s roditeljima u istraživanjima (npr. kao rezultat na upitniku ili kao rezultat na čestici), a nije jasno ni jesu li djetetova i roditeljeva percepcija njihova odnosa usklađene. Kako je zadovoljstvo odnosom s roditeljima i u ovom istraživanju operacionalizirano kao rezultat na jednoj čestici (odnosno česticama zasebno za that father's university education is a potential protective factor for drinking alcohol in adolescents. Recent research shows a shift from the traditional role of the father as a caretaker and authority, as well as a trend towards greater inclusion of fathers in the education and lives of children (Cvrtnjak and Miljević-Riđički, 2015). Fathers with a higher education level achieve higher scores on parental inclusion scales and positive parenting than fathers with lower education levels, and use more diverse educational and disciplinary techniques (Hadjicharalambous, 2021). Education develops competencies at many levels and, consequently, has effects on health (Ross and Mirowsky, 2011). A high level of education increases the feeling of personal control (Mirowsky and Ross, 2003), which contributes to making decisions on healthy lifestyles. Compared to people who feel powerless, people with a sense of personal control are more likely to stop smoking, start exercising and consume alcohol moderately (Mirowsky and Ross, 1998), with parental alcohol consumption a risk factor for adolescent consumption (Smith, Voogt, Otten, Kleinjan and Kuntsche, 2019; Waddell, Blake, Sternberg, Ruoff and Chassin, 2020). Exposure to paternal alcohol consumption in childhood proved to have had an effect on adolescents' expectations of alcohol consumption, while exposure to maternal consumption did not have such effects (Smith et al., 2019).

\section{Relationship between Alcohol Consumption Habits and Perception of Parental Monitoring, Relations with Parents and Expected Parental Reaction to Drinking}

Adolescents who think that their parents approve of drinking are more inclined to drink than those who think their parents would not approve of such behavior. It is interesting that the expected reactions of the father and mother 
oca i majku) tako je moguće da takva operacionalizacija nije adekvatna operacionalizacija konstrukta, što može objasniti rezultate neusklađene $s$ dosadašnjim istraživanjima. $U$ studijama koje nalaze povezanost konzumacije alkohola i odnosa s roditeljima nije moguće donijeti zaključak o kauzalnosti i potencijalnoj recipročnosti tog odnosa (Visser i sur., 2012). Osim toga, prema nekim studijama (Catalano i sur., 2002; Hemphill, Heerde i Herrenkohl, 2011) konzumacija sredstava ovisnosti povezuje se s konfliktima u obitelji, a dinamika obitelji u cjelini ne mora nužno biti povezana sa zadovoljstvom odnosa s pojedinim roditeljem. Moguće je i da su druženje s devijantnim vršnjacima i roditeljsko prezaštićivanje medijatori veze konzumacije alkohola i odnosa s roditeljima (Visser i sur., 2012). Visser i suradnici (2012) pretpostavljaju da devijantni vršnjaci utječu na konzumaciju alkohola, a druženje s njima vodi do sukoba s roditeljima koji narušava odnos. Alkohol ujedno može biti način protesta protiv roditeljskog prezaštićivanja, koje također vodi sukobima i narušava odnos. Autori (Visser i sur., 2012) zaključuju da preventivni programi usmjereni samo na poboljšanje odnosa roditelja i djeteta vjerojatno neće biti učinkoviti, no odnos s roditeljima ostaje zaštitni čimbenik te, unatoč nejasnim procesima u pozadini, loš odnos s roditeljima može pomoći u identifikaciji adolescenata koji su u riziku od konzumacije alkohola.

\section{Doprinos sociodemografskih varijabli, percepcije nadzora i percepcije reakcija roditelja u predviđanju konzumacije alkohola i učestalosti opijanja u životu i u posljednjih mjesec dana}

Temeljem dobi, roda, percepcije roditeljskog nadzora i očekivanih reakcija roditelja moguće je previdjeti 33,7\% varijabiliteta konzumacije alkohola u životu i $22,3 \%$ varijabiliteta are in a high correlation $(R=0.738)$, which may indicate a high proportion of parental attitudes towards alcohol consumption. The ratio of perceived parental attitudes to alcohol with the frequency of consumption is in line with expectations (Farrington, 1995; Mihić et al., 2013). A lack of parental non-approval of children's anti-social behavior and a lack of discipline related to engaging in risk behaviors can contribute to developing an inadequate value system in adolescents in which they will be more prone to alcohol consumption (Farrington, 1995; Ferić-Šlehan, 2008).

Dichotomizing the variable of alcohol consumption on a monthly basis to occasional and frequent drinkers showed that, in the group of frequent drinkers, parents less frequently have clear rules of conduct outside home, and are less often aware about where and who their children socialize with. Family rules and parental information about adolescent activities are related to the use of addictive substances (Kandel and Andrews, 1987; Ennett, Bauman, Foshee, Pemberton and Hicks, 2001), and, in addition to the quality of communication and the child's confidence in the parents, the level of information reduces the likelihood of adolescent involvement in inappropriate behaviors (Mihić et al., 2013).

Although satisfaction with relations with parents is an important protective factor (Hawkins et al., 1992), this research did not suggest a link between adolescent alcohol consumption with satisfaction with relations with parents. These results are in line with conclusions of the review paper on the effects of parental and child relations on the consumption of alcohol in young people (Visser, Winter and Reijneveld, 2012). Most studies (16) do not establish a link between alcohol consumption and relations with parents, seven studies find this link for particular subgroups (e.g. boys or girls only), 
konzumacije alkohola u posljednjih mjesec dana, a kao najbolji prediktor konzumacije alkohola ističe se dob. Dob, rod, percepcija roditeljskog nadzora, očekivane reakcije roditelja na opijanje i učestalost konzumacije alkohola u posljednjih mjesec dana predviđaju zajedno $40,3 \%$ varijabiliteta učestalosti opijanja u životu i $24,3 \%$ varijabiliteta učestalosti opijanja u posljednjih mjesec dana, pri čemu se kao najbolji prediktor učestalosti opijanja za oba kriterija ističe procjena konzumacije alkohola u zadnjih 30 dana.

lako doprinos roditeljskih varijabli nije zanemariv, one u kombinaciji sa sociodemografskim podatcima predviđaju tek manji dio varijabiliteta konzumacije alkohola među adolescentima. Ostatak varijabiliteta vjerojatno je objašnjiv ostalim obiteljskim čimbenicima koji nisu bili ispitivani u ovom istraživanju. lako je neprijeporan utjecaj roditelja, obitelji, ali i drugih odraslih, konzumacija alkohola kod adolescenata tumači se još i utjecajem vršnjaka i društvenim kontekstom u kojem mladi odrastaju. Kasna je adolescencija vrijeme u kojem se smanjuje utjecaj i nadzor roditelja te adolescentu postaju važni vršnjaci i osjećaj pripadnosti drugima (Santor, Messervey i Kusumakar, 2000). Postoje brojni nalazi koji povezuju konzumaciju alkohola i opijanje s utjecajem vršnjaka i vršnjačkim pritiskom (Nash, McQueen i Bray, 2004) te uvjerenjem da svi ili većina vršnjaka pije i opija se ili da neće biti uhvaćeni i kažnjeni (Song, Smiler, Wagoner i Wolfson, 2012).

\section{Implikacije i prijedlozi za buduća istraživanja}

Jedna od glavnih prednosti istraživanja svakako je reprezentativan uzorak koji nudi mogućnost generalizacije rezultata na adolescente iz područja Splitsko-dalmatinske županije. Takav uvid u navike pijenja adolescenata temelj je za epidemiološku podlogu preventivnih aktivnosti u županiji te nudi okvir za and only five studies find that poor relations with parents are associated with higher alcohol consumption (Visser et al., 2012). Visser et al. (2012) explain the inconsistency of research findings (2012) by different operationalizations of relations with parents in the research (e.g. as results obtained from a questionnaire or on a unit), while it is also unclear whether the child's and parents' perceptions of their relationship are harmonized. Since this research operationalized satisfaction with relations with parents as a result on a single unit (or separate units for father and mother), it is possible that this is not an adequate operationalization of the construct, which may explain the inconsistency of the results with previous research. Studies that do establish a link between alcohol consumption and relations with parents, however, are not conclusive about the causality and potential reciprocity of that relationship (Visser et al., 2012). In addition, according to some studies (Catalano et al., 2002; Hemphill, Heerde and Herrenkohl, 2011), consumption of addictive substances is associated with conflicts in the family, and dynamics of the family as a whole is not necessarily related to satisfaction with relations with individual parents. It is also possible that socializing with deviant peers and parental overprotection are mediators of the link between alcohol consumption and relations with parents (Visser et al., 2012). Visser et al. (2012) assume that deviant peers influence alcohol consumption, while socializing with them leads to conflicts with parents, which is detrimental to relations. Alcohol can also be a way of protesting parental overprotection, which also leads to conflicts that disturb relations. The authors (Visser et al., 2012) conclude that preventive programmes aimed solely at improving relations between parents and children are unlikely to be effective, but that relations with parents remain a protective factor and, despite unclear background processes, poor relations 
Roberta Matković, Ana Petak, Željko Ključević: Odnos navika konzumacije alkohola i percepcije roditeljskih...

pravovremenu preventivnu intervenciju (Small, Cooney i O'Connor, 2009), što bi značilo da preventivne programe usmjerene na djecu i roditelje treba omogućiti netom prije početka konzumacije alkohola da bismo osigurali pozitivne ishode preventivne intervencije. Dobiveni rezultati doprinos su $\mathrm{u}$ istraživanju rizičnih $\mathrm{i}$ zaštitnih čimbenika obiteljskog okruženja za konzumaciju alkohola među mladima te upućuju na potrebu za proširivanjem nacrta dodatnim varijablama vezanima uz odgoj i roditeljstvo.

Dobivene rezultate važno je sagledati u kontekstu primijenjene metodologije i načina predstavljanja konstrukata. Varijable vezane uz roditeljski nadzor, očekivane reakcije roditelja i zadovoljstvo odnosom s roditeljima nisu predstavljene rezultatom na psihometrijskom instrumentu već su zastupljene s po jednom česticom u upitniku te je moguće da ne predstavljaju u potpunosti adekvatnu mjeru konstrukta. Prijedlog za buduća istraživanja je primjena konstrukta koji bi bolje opisivao roditeljski nadzor i kontrolu, uparivanje rezultata roditelja i adolescenata uz utvrđivanje stilova roditeljstva, tehnika kojima se roditelji služe pri discipliniranju svoje djece, stavova roditelja prema konzumaciji alkohola te navike konzumacije alkohola kod roditelja. Također, pokazala se potreba za provjerom medijatorskog učinka očeva obrazovanja na odnos njegove konzumacije alkohola i konzumacije alkohola adolescenta te provjera interakcijskih učinaka odgojnih postupaka. Jedan je od smjerova budućih istraživanja utvrđivanje ostalih čimbenika (poput vršnjačkog utjecaja, dostupnosti alkohola, prisutnosti internaliziranih ili eksternaliziranih problema i sl.) koji bi uz roditeljstvo i odgoj mogli djelovati na konzumaciju alkohola među mladima. Unatoč prisutnim metodološkim nedostatcima i brojnim otvorenim pitanjima, ovo istraživanje nudi vrijedan doprinos razumijevanju odnosa konzumacije alkohola i načina with parents can help identify adolescents at risk of alcohol consumption.

\section{Contribution of Socio-Demographic Variables, Perception of Parental Monitoring and of Parental Reactions in Predicting Alcohol Consumption and Frequency of Intoxication in Life and in the Last Month}

Based on age, gender, and perception of parental monitoring and of expected parental reactions, it is possible to predict $33.7 \%$ of variability of alcohol consumption in life and $22.3 \%$ of variability of alcohol consumption in the last month, while the best predictor of alcohol consumption is age. Age, gender, perception of parental monitoring and expected parental reactions to intoxication, and frequency of alcohol consumption in the last month together predict $40.3 \%$ of variability in the frequency of intoxication in life and $24.3 \%$ of variability in the frequency of intoxication in the last month, with assessment of alcohol consumption in the last 30 days standing out as the best predictor of the frequency of intoxication for both criteria.

Although the contribution of parental variables is not negligible, combined with socio-demographic data, they predict only a small portion of the variability of alcohol consumption among adolescents. The remaining variability can probably be explained by other family factors that were not examined in this study. Although the influence of parents, families and other adults is undisputable, alcohol consumption in adolescents is also interpreted through peer influence and the social context in which young people grow up. Late adolescence is a time in which parental influence and monitoring is diminished, when adolescents attach more importance to peers and the sense of belonging to others (Santor, Messervey and Kusumakar, 2000). There are numerous findings linking 
na koji adolescenti percipiraju i predviđaju neka roditeljska ponašanja.

\section{ZAKLJUČAK}

Prikazani podatci upozoravaju na zabrinjavajući trend konzumacije alkohola kod adolescenata te na njegovu povezanost s percepcijom roditeljskog nadzora i percepcijom mladih o tome kakvi su stavovi njihovih roditelja prema opijanju. lako su navedene adolescentske percepcije nekih roditeljskih ponašanja potencijalnih rizičnih čimbenika za konzumaciju alkohola među mladima, one su samo dio čimbenika koji doprinose rizičnom ponašanju mladih. Znanja o zaštitnim i rizičnim čimbenicima vrlo su važna, no potrebno je „prevođenje" tih znanja u sustave prevencije u lokalne zajednice koje će zaista reducirati prevalenciju poteškoća kod djece i mladih (Hawkins, Catalano i Arthur, 2002). Važno je prepoznati ključne rizične čimbenike koji doprinose ranoj konzumaciji sredstava ovisnosti, a potom i one povezane s učestalosti konzumacije, da bi se prevenciji moglo pristupiti pravovremeno i sustavno. S obzirom na epidemiološke pokazatelje, nužna su daljnja istraživanja koja će razjasniti koje zaštitne čimbenike jačati da bi se što učinkovitije pristupilo prevenciji konzumacije sredstava ovisnosti među mladima. alcohol consumption and intoxication to peer influence and pressure (Nash, McQueen and Bray, 2004), and to belief that all or most peers drink and get drunk, or that they will not be caught and punished (song, Smiler, Wagoner and Wolfson, 2012).

\section{Implications and Recommendations for Further Research}

One of the key advantages of the research certainly is its representative sample providing the possibility of generalizing the results for adolescents from the Split-Dalmatia County. Such insight into adolescents' drinking habits provides grounds for an epidemiological basis for preventive activities in the county, and offers a framework for timely preventive intervention (Small, Cooney and O'Connor, 2009), meaning that preventive programs targeting children and parents should be provided just before the beginning of alcohol consumption in order to ensure positive outcomes of preventive intervention. The results obtained are a contribution to researching risk and protective factors of the family environment for alcohol consumption among young people, and indicate the need to expand the draft with additional variables related to education and parenting.

The results obtained should be taken into account in the context of the methodology applied and the way in which constructs are presented. The variables related to parental monitoring, expected parental reactions and satisfaction with relations with parents are not presented through results on a psychometric instrument, but are represented with a single questionnaire unit, and possibly do not fully represent the adequate measure of the construct. A proposal for future research is to apply constructs that would better describe parental monitoring and control, pair parents' and adolescents results with a determination 
of parenting styles, techniques used by parents to discipline their children, parental attitudes towards alcohol consumption, and alcohol consumption habits in parents. Additionally, a need arose to check the mediating effect of the father's education level on the relationship between his and the adolescent's alcohol consumption, and check the interaction effects of educational procedures. One of the directions of future research is to determine other factors (such as peer influence, availability of alcohol, presence of internalized or externalized problems, etc.) that could influence alcohol consumption in young people along with parenting and education. Despite the present methodological shortcomings and numerous open questions, this research offers a valuable contribution to understanding the relationship between alcohol consumption and the way in which adolescents perceive and anticipate some parental behaviors.

\section{CONCLUSION}

The presented data indicate a worrying trend in alcohol consumption in adolescents, as well as its connection with the perception of parental monitoring and young people' perceptions of their parents' attitudes towards drinking. Although adolescent perceptions of some parental behaviors are noted as potential risk factors for alcohol consumption among young people, they are just a part of the factors that contribute to risk behavior of young people. Knowledge about protective and risk factors is very important, but it is necessary to "translate" this knowledge into prevention systems in local communities that will actually reduce the prevalence of problems among children and young people (Hawkins, Catalano and Arthur, 2002). It is important to identify key risk factors contributing to early 
consumption of addictive substances, and then those related to frequency of consumption, so that prevention can be addressed in a timely and systematic manner. Given epidemiological indicators, further research is required to clarify which protective factors need to be strengthened in order to approach the prevention of consumption of addictive substances among young people as effectively as possible. 


\section{LITERATURA / REFERENCES}

Aggarwal, R. i Ranganathan, P. (2016). Common pitfalls in statistical analysis: The use of correlation techniques. Perspectives in clinical research, 7(4), 187-190. https://doi.org/10.4103/22293485.192046

Bahr, S. J., Hoffmann, J. P. i Yang, X. (2005). Parental and Peer Influences on the Risk of Adolescent Drug Use. The Journal of Primary Prevention, 26(6), 529-51. https://doi.org/10.1007/s10935005-0014-8

Bašić, J. (2009). Teorije prevencije: Prevencija poremećaja u ponašanju i rizičnih ponašanja djece $i$ mladih. Zagreb: Školska knjiga.

Bjarnason T. (2000). Adolescent Substance Use: A Study in Durkheimian Sociology. [Doctoral dissertation]. Indiana: University of Notre Dame.

Bouillet, D. i Čale-Mratović, M. (2007). Konzumiranje alkoholnih pića i doživljaj škole. Hrvatska revija za rehabilitacijska istraživanja, 43(2), 17-27.

Bronfenbrenner, U. (1974). Developmental research, public policy, and the ecology of childhood. Child development, 45(1), 1-5. https://doi.org/10.2307/1127743

Catalano, R. F., Hawkins, J. D., Berglund, M. L., Pollard, J. A. i Arthur, M. W. (2002). Prevention science and positive youth development: competitive or cooperative frameworks?. The Journal of adolescent health: official publication of the Society for Adolescent Medicine, 31(6), 230-239. https:// doi.org/10.1016/s1054-139x(02)00496-2

Cleveland, M. J., Feinberg, M. E., Bontempo, D. E. i Greenberg, M. T. (2008). The role of risk and protective factors in substance use across adolescence. The Journal of adolescent health: official publication of the Society for Adolescent Medicine, 43(2), 157-164. https://doi.org/10.1016/j. jadohealth.2008.01.015

Currie, C., Zanotti, C., Morgan, A., Currie, D., de Looze, M., Roberts, C., Samdal, O., Smith, O. R. F. i Barnekow, V. (2012). Social determinants of health and well-being among young people. Health Behaviour in School-aged Children (HBSC) study: international report from the 2009/2010 survey. Health Policy for Children and Adolescents, 6. Copenhagen: WHO, Regional Office for Europe.

Cvrtnjak, I. i Miljević Riđički, R. (2015). Očevi nekad i danas. Život i škola, LXI(1), 113-119.

Dawson, D. (1996). Gender differences in the risk of alcohol dependence: United States, 1992. Addiction, 91(12), 1831-1842. https://doi.org/10.1046/j.1360-0443.1996.911218317.x

DeFrain, J. (2001). Creating a Strong Family: Why are Families so Important?. Historical Materials from University of Nebraska-Lincoln Extension, 343. Preuzeto s: https://digitalcommons.unl.edu/ extensionhist $/ 343$

Desjardins, J., Zelenski, J. M. i Coplan, R. J. (2008). An investigation of maternal personality, parenting styles and subjective well-being. Personality and Individual Difference, 44(3), 587-597. https:// doi.org/10.1016/j.paid.2007.09.020

Domitrović, I. i Županić, M. (2016). Zastupljenost konzumiranja alkohola kod adolescenata. Hrvatski časopis za javno zdravstvo, 12(45), 20-37.

Ennett, S. T., Bauman, K. E., Foshee, V. A., Pemberton, M. i Hicks, K. A. (2001). Parent-child communication about adolescent tobacco and alcohol use: What do parents say and does it affect youth behavior? Journal of Marriage and Family, 63(1), 48-62. https://doi.org/10.1111/j.17413737.2001.00048.x 
ESPAD Group. (2020a). ESPAD Report 2019: Additional Tables. Luxemburg: Publications Office of the European Union.

ESPAD Group. (2020b). ESPAD Report 2019: Results from the European School Survey Project on Alcohol and Other Drugs. Luxembourg: EMCDDA Joint Publications, Publications Office of the European Union.

European Monitoring Center for Drugs and Drug Addiction - EMCDDA. (2008). Drugs and vulnerable groups of young people. Preuzeto s: https://www.emcdda.europa.eu/system/files/publications/499/EMCDDA_SI08_vulnerable-young_121281.pdf (01.05.2021.)

European School Survey Project on Alcohol and Other Drugs - ESPAD. (2020). Additional tables source data (zip file.) Preuzeto s: http://www.espad.org/sites/espad.org/files/espad-report-2019-additional-tables.zip (01.05.2021.)

Farrington, D. P. (1995). The twelfth Jack Tizard memorial lecture. The development of offending and antisocial behaviour from childhood: key findings from the Cambridge Study in Delinquent Development. Journal of Child Psychology and Psychiatry, 36(6), 929-964. https://doi. org/10.1111/j.1469-7610.1995.tb01342.x

Ferić, M. (2002). Obitelj kao čimbenik rizika i zaštite za razvoj poremećaja u ponašanju djece i mladih. Hrvatska revija za rehabilitacijska istraživanja, 38(1), 13-24.

Ferić-Šlehan, M. (2008). Rizični i zaštitni čimbenici u obiteljskom okruženju: razlike u procjeni mladih i njihovih roditelja. Hrvatska revija za rehabilitacijska istraživanja, 44(1), 15-26.

Gajnik, D. i Koražija, N. (2008). Navika pušenja, konzumiranja alkohola i opojnih sredstava učenika šestih razreda osnovnih škola i program prevencije „Dobro nije što se puši, guta, pije” u Zagrebačkoj županiji. Hrvatski časopis za javno zdravstvo, 4(16).

Glavak Tkalić, R., Miletić, G. M. i Sakoman, S. (2013). Prevalence of substance use among the general population: Situation in Croatia and comparison with other European countries. Društvena istraživanja, 22(4), 557-578. https://doi.org/10.5559/di.22.4.01

Glavak Tkalić, R., Miletić, G. M., Maričić, J. i Wertag, A. (2012). Zlouporaba sredstava ovisnosti u općoj populaciji Republike Hrvatske: istraživačko izvješće. Institut društvenih znanosti Ivo Pilar i Ured za suzbijanje zlouporabe droga Vlade Republike Hrvatske, Zagreb.

Hadjicharalambous, D. (2021). Examining the Influence of Father's and Mother's Characteristics in Positive and Negative Parenting Practices. International Journal of Social Science And Human Research, 4(1), 481-489. https://doi.org/10.47191/ijsshr/v4-i1-04

Hanson, M. D. i Chen, E. (2007) Socioeconomic status and health behaviors in adolescence: a review of the literature. Journal of Behavioral Medicine 30(263), 263-285. https://doi.org/10.1007/ s10865-007-9098-3

Haug, S., Schaub, M. P., Salis Gross, C., John, U. i Meyer, C. (2013). Predictors of hazardous drinking, tobacco smoking and physical inactivity in vocational school students. BMC Public Health, 13, 475. https://doi.org/10.1186/1471-2458-13-475

Hawkins, J. D., Catalano, R. E. i Miller, J. Y. (1992). Risk and protective factors for alcohol and other drug problems in adolescence and early adulthood. Implications for Substance Abuse Prevention, 112(1), 64-105. https://doi.org/10.1037/0033-2909.112.1.64

Hawkins, J. D., Catalano, R. i Arthur, M. (2002). Promoting science-based prevention in communities. Addict Behav, 27(6), 951-976. https://doi.org/10.1016/s0306-4603(02)00298-8 
Hemphill, S. A., Heerde, J. S. i Herrenkohl, T. D. (2011). Risk and protective factors for adolescent substance use in Washington State, United States and Victoria, 55 Australia: A longitudinal study. Journal of Adolescent Health, 49(3), 312-320. https://doi.org/10.1016/j.jadohealth.2010.12.017

Hung, C. C., Yen, L. L. i Wu, W. C. (2009). Association of parents' alcohol use and family interaction with the initiation of alcohol use by sixth graders: A preliminary study in Taiwan. BMC Public Health, 9, 172. https://doi.org/10.1186/1471-2458-9-172

Inchley, J., Currie, D., Vieno, A., Torsheim, T., Ferreira-Borges, C., Weber, M. M., Vivian Barnekow, V. i João Breda, J. (2018). Adolescent alcohol-related behaviours: trends and inequalities in the WHO European Region, 2002-2014. Copenhagen: WHO. Preuzeto s: https://www.euro.who.int/_data/ assets/pdf_file/0007/382840/WH15-alcohol-report-eng.pdf (15. 2. 2021.)

Jackson, K. M., Barnett, N. P., Colby, S. M. i Rogers, M. L. (2015). The prospective association between sipping alcohol by the sixth grade and later substance use. Journal of Studies on Alcohol and Drugs, 76(2), 212-221. https://doi.org/10.15288/jsad.2015.76.212

Johannessen, E. L., Andersson, H. W., Bjørngaard, J. H. i Pape, K. (2017). Anxiety and depression symptoms and alcohol use among adolescents - a cross sectional study of Norwegian secondary school students. BMC Public Health, 17(1). https://doi.org/https://doi.org/10.1186/s12889-0174389-2

Kalebić Maglica, B. i Martinac Dorčić, T. (2015). Osobine ličnosti i socijalni faktori kao odrednice konzumacije cigareta i alkohola kod adolescenata. Društvena istraživanja, 24(2), 197-217. https:// doi.org/10.5559/di.24.2.02

Kandel, D. B. i Andrews, K. (1987). Processes of adolescent socialization by parents and peers. International Journal of the Addictions, 22(4), 319-342. https://doi.org/10.3109/10826088709027433

Kokkevi, A., Richardson, C., Florescu, S., Kuzman, M. i Stergar, E. (2007). Psychosocial correlates of substance use in adolescence: A cross-national study in six European countries. Drug and Alcohol Dependence, 86(1), 67-74. https://doi.org/10.1016/j.drugalcdep.2006.05.018

Kumpfer, K. L., Smith, P. i Summerhays, J. F. (2008). A wakeup call to the prevention field: Are preven tion programs for substance use effective for girls? Substance Use \& Misuse, 43(8), 978-1001. https://doi.org/10.1080/10826080801914261

Kurdek, L. A. (2003). Correlates of parents' perception of behavioral problems in their young chiIdren. Journal of Applied Developmental Psychology, 24(4), 457-473. https://doi.org/10.1016/ S0193-3973(03)00071-6

Kuzman, M. i Katalinić, D. (2005). Čimbenici rizika i ovisničko ponašanje u mladih. Zagreb: Hrvatski zavod za javno zdravstvo.

Latendresse, S. J., Rose, R. J., Viken, R. J., Pulkkinen, L., Kaprio, J. i Dick, D. M. (2008). Parenting mechanisms in links between parents' and adolescents' alcohol use behaviors. Alcoholism, clinical and experimental research, 32(2), 322-330. https://doi.org/10.1111/j.1530-0277.2007.00583.x

Lengua, L. J., Honorado, E. i Bush, N. (2007). Contextual risk and parenting as predictors of effortful control and social competence in preschool children. Journal of Applied Developmental Psychology, 28(1), 40-55. https://doi.org/10.1016/j.appdev.2006.10.001

Livingston, M., Laslett, A. M. i Dietze, P. M. (2008). Individual and community correlates of young people's high-risk drinking in Victoria, Australia. Drug and Alcohol Dependence, 98(3). https:// doi.org/10.1016/j.drugalcdep.2008.06.002

Ljubotina, D. i Galić, J. (2002). Obiteljski odnosi i konzumacija droga na populaciji adolescenata grada Zagreba. Ljetopis Studijskog centra socijalnog rada, 9(2), 207-232. 
Melotti, R., Lewis, G., Hickman, M., Heron, J., Araya, R. i Macleod, J. (2013). Early life socio-economic position and later alcohol use: birth cohort study. Addiction, 108(3), 516-525. https://doi. org/10.1111/add.12018

Merkle, E. i Richardson, R. (2000). Digital Dating and Virtual Relating: Conceptualizing Computer Mediated Romantic Relationships. Family Relations, 49(2), 187-192. https://doi.org/10.1111/ j.1741-3729.2000.00187.x

Meunier, J. C., Roskam, I., Stievenart, M., van de Moortele, G., Browne, D. T. i Kumar, A. (2011). Externalizing behavior trajectories: The role of parenting, sibling relationships and child personality. Journal of Applied Developmental Psychology, 32(1), 20-33. https://doi.org/10.1016/j. appdev.2010.09.006

Mihić, J., Musić, T. i Bašić, J. (2013). Obiteljski rizični i zaštitni čimbenici kod mladih nekonzumenata i konzumenata sredstava ovisnosti. Kriminologija i socijalna integracija, 21(1), 49-63.

Mirowsky, J. i Ross, C. E. (1998). Education, personal control, lifestyle and health: a human capital hypotheses. Research on Aging, 20(4), 415-449. https://doi.org/10.1177/0164027598204003

Mirowsky, J. i Ross, C. E. (2003). Education, social status, and health. New York: Aldine Transaction.

Nash, S. G., McQueen, A. i Bray, J. H. (2005). Pathways to adolescent alcohol use: family environment, peer influence, and parental expectations. The Journal of adolescent health: official publication of the Society for Adolescent Medicine, 37(1), 19-28. https://doi.org/10.1016/j.jadohealth.2004.06.004

National Institute on Alcohol Abuse and Alcoholism [NIAAA]. (2004). The Effects of Alcohol on Physiological Processes and Biological Development. Alcohol research \& health: the journal of the National Institute on Alcohol Abuse and Alcoholism, 28(3), 125-131.

Nolen-Hoeksema, S. (2004). Gender differences in risk factors and consequences for alcohol use and problems. Clinical Psychology Review, 24(8), 981-1010. https://doi.org/10.1016/j.cpr.2004.08.003

Obot, I. S. i Room, R. (Ur.). (2005). Alcohol, gender and drinking problems. Geneva: World Health Organization, Department of Mental Health and Substance Abuse. Preuzeto s: http://www.who. int/substance_abuse/publications/alcohol_gender_drinking_problems.pdf (15.2. 2021.)

Pejnović Franelić, I., Markelić, M., Muslić, Lj., Musić Milanović, S., Pavić Šimetin, I., Mayer, D. i Jovičić Burić, D. (2016). Europsko istraživanje o pušenju, pijenju i uzimanju droga među učenicima ESPAD. Prikaz hrvatskih nacionalnih rezultata. Zagreb: Hrvatski zavod za javno zdravstvo.

Pett, M. A. (2016). Nonparametric Statistics for Health Care Research. Sage Publications.

Piko, B. F. (2006). Adolescent smoking and drinking: The role of communal mastery and other social influences. Addictive Behaviors, 31(1), 102-114. https://doi.org/10.1016/j.addbeh.2005.04.013

Pirkle, E. C. i Richter, L. (2006). Personality, attitudinal and behavioral risk profiles of young female binge drinkers and smokers. Journal of Adolescent Health, 38(1), 44-54. https://doi.org/10.1016/j. jadohealth.2004. 09.012

Pollard, J. A., Hawkins, J. D. i Arthur, M. W. (1999). Risk and protection: Are both necessary to understand diverse behavioral outcomes in adolescence?. Social Work Research, 23(3), 145-158. https://doi.org/10.1093/swr/23.3.145

Ross, C. E. i Mirowsky, J. (2011). The interaction of personal and parental education on health. Social Science \& Medicine, 72(4), 591-599. https://doi.org/10.1016/j.socscimed.2010.11.028

Sakoman, S., Kuzman, M. i Raboteg-Šarić, Z. (1999). Čimbenici rizika i obilježja navika pijenja alkoholnih pića među srednjoškolcima. Društvena istraživanja, 8(2-3), 373-398. 
Roberta Matković, Ana Petak, Željko Ključević: Odnos navika konzumacije alkohola i percepcije roditeljskih...

Sale, E., Sambrano, S., Springer, F. J. i Turner, C. (2003). Risk, protection, and substance use in adolescents: A multi-site model. Journal of Drug Education, 33(1), 91-105. https://doi.org/10.2190/ LFJ0-ER64-1FVY-PA7L

Samardžić, S., Bujšić, G., Kožul, K. i Tadijan, D. (2011). Drinking in Adolescents - Qualitative Analysis. Collegium antropologicum, 35(1), 123-126.

Santor, D. A., Messervey, D. i Kusumakar, V. (2000). Measuring peer pressure, popularity, and conformity in adolescent boys and girls: Predicting school performance, sexual attitudes and substance abuse. Journal of Youth and Adolescence, 29, 163-182. https://doi.org/10.1023/A:1005152515264

Shek, D. T. L. (2006). Perceived parent-child relational qualities and parental behavioral and psychological control in Chinese adolescents in Hong Kong. Adolescence, 41(163), 563-581.

Skreitule-Pikse, I., Sebre, S. i Lubenko, J. (2010). Child behavior and mother-child emotional availability in response to parent training program: moderators of outcome. Procedia Social and Behavioral Sciences, 5, 1418-1424. https://doi.org/10.1016/j.sbspro.2010.07.299

Small, S. A., Cooney, S. M. i O'Connor, C. (2009). Evidence-Informed Program Improvement: Using Principles of Effectiveness to Enhance the Quality and Impact of Family-Based Prevention Programs. Family Relations, 58(1), 1-13. https://psycnet.apa.org/doi/10.1111/j.1741-3729.2008.00 530.x

Smit, K., Voogt, C., Otten, R., Kleinjan, M. i Kuntsche, E. (2019). Exposure to Parental Alcohol Use Rather Than Parental Drinking Shapes Offspring's Alcohol Expectancies. Alcohol Clin Exp Res, 43, 1967-1977. https://doi.org/10.1111/acer.14139

Song, E. Y., Smiler, A. P., Wagoner, K. G. i Wolfson, M. (2012). Everyone says it's ok: adolescents' perceptions of peer, parent, and community alcohol norms, alcohol consumption, and alcohol-related consequences. Substance use \& misuse, 47(1), 86-98. https://doi.org/10.3109/108 26084.2011.629704

Spudić, M. i Kosić, R. (2020). Alkoholizam kod mladih. Sestrinski glasnik, 25(2), 104-8.

Štimac Grbić, D. i Glavak Tkalić, R. (ur.). (2020). Uporaba sredstava ovisnosti u općoj populaciji Republike Hrvatske: 2019. i analiza trendova uporabe 2011.-2019. Zagreb: Hrvatski zavod za javno zdravstvo i Institut društvenih znanosti Ivo Pilar.

Torikka, A., Kaltiala-Heino, R., Luukkaala, T. i Rimpelä, A. (2017). Trends in Alcohol Use among Adolescents from 2000 to 2011: The Role of Socioeconomic Status and Depression. Alcohol and alcoholism, 52(1), 95-103. https://doi.org/10.1093/alcalc/agw048

Tuinstra, J., Groothoff, J. W., Van Den Heuvel, W. J. A. i Post, D. (1998). Socio-economic differences in health risk behavior in adolescence: Do they exist? Social Science \& Medicine, 47(1), 67-74. https://doi.org/10.1016/S0277-9536(98)00034-3

Visser, L., de Winter, A. F. i Reijneveld, S. A. (2012). The parent-child relationship and adolescent alcohol use: a systematic review of longitudinal studies. BMC Public Health 12, 886. https://doi. org/10.1186/1471-2458-12-886

Vrselja, I. i Glavak Tkalić, R. (2011). Odnos između rizičnog i delinkventnog ponašanja, nekih obiteljskih kontekstualnih čimbenika i roditeljskih odgojnih metoda. Kriminologija i socijalna integracija, 19(1), 51-62.

Waddell, J.T., Blake, A.J., Sternberg, A., Ruof, A. i Chassin, L. (2020). Effects of Observable Parent Alcohol Consequences and Parent Alcohol Disorder on Adolescent Alcohol Expectancies. Alcoholism: Clinical \& Experimental Research, 44, 973-982. https://doi.org/10.1111/acer.14298 
Waller, R., Murray, L., Shaw, D. S., Forbes, E. E. i Hyde, L. W. (2019). Accelerated alcohol use across adolescence predicts early adult symptoms of alcohol use disorder via reward-related neural function. Psychological medicine, 49(4), 675-684. https://doi.org/10.1017/S003329171800137X

Wiles, N. J., Lingford-Hughes, A., Daniel, J., Hickman, M., Farrell, M., Macleod, J., Haynes, J. C., Skapinakis, P., Araya, R. i Lewis, G. (2007). Socio-economic status in childhood and later alcohol use: a systematic review. Addiction, 102(10), 1546-1563. https://doi.org/10.1111/j.13600443.2007.01930.x

Windle M. (2003). Alcohol use among adolescents and young adults. Alcohol research \& health : the journal of the National Institute on Alcohol Abuse and Alcoholism, 27(1), 79-85.

Witt, E. D. (2007). Puberty, hormones and sex differences in alcohol abuse and dependence. Neurotoxicology and Teratology, 29(1), 81-95. https://doi.org/10.1016/j.ntt.2006.10.013 